Supporting information

\title{
Total Synthesis of (+)-Mycalamide A
}

\author{
Natsuko Kagawa, Masataka Ihara, and Masahiro Toyota* \\ Department of Chemistry, Graduate School of Science, Osaka Prefecture University, Sakai, Osaka \\ 599-8531, Japan \\ E-mail: toyota@c.s.osakafu-u.ac.jp
}




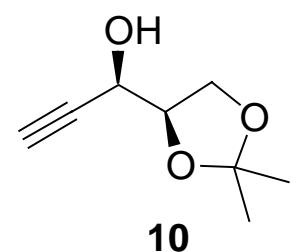

\section{(+)-(2R,3R)-1,2-O-Isopropylidene-4-pentyne-1,2,3-triol (10)}

To a $-30{ }^{\circ} \mathrm{C}$ solution of $p$-nitrobenzoic acid $(0.156 \mathrm{~g}, 0.934 \mathrm{mmol})$ and powdered $\mathrm{PPh}_{3}(0.245 \mathrm{~g}$, $0.934 \mathrm{mmol})$ in toluene $(10 \mathrm{~mL})$ was added a solution of anti-alcohol 9 (0.178 g, $0.779 \mathrm{mmol})$ in toluene $(3 \mathrm{~mL})$, and followed by a solution of DEAD in toluene $(0.424 \mathrm{~mL}, 40 \%, 0.934 \mathrm{mmol})$. The mixture was stirred for $17 \mathrm{~h}$ at $-30{ }^{\circ} \mathrm{C}$, then poured into saturated $\mathrm{NaHCO}_{3}(20 \mathrm{~mL})$. The phases were separated and the aqueous phase was further extracted with $\mathrm{Et}_{2} \mathrm{O}(2 \mathrm{x} 40 \mathrm{~mL})$. The combined organic extracts were washed with brine $(20 \mathrm{~mL})$, dried $\left(\mathrm{MgSO}_{4}\right)$ and concentrated. The resulting yellow solid was diluted with $\mathrm{Et}_{2} \mathrm{O}(9 \mathrm{~mL})$ and hexane $(30 \mathrm{~mL})$, and filtered. The filter cake was washed with $\mathrm{Et}_{2} \mathrm{O}$, and combined filtrate and washings were evaporated to provide a viscous oil. Purification of the crude product by flash chromatography (9\% EtOAc/hexane) provided syn-p-nitrobenzoate $(0.462 \mathrm{~g},>100 \%)$ as a yellow solid, which was used without further purification in a next experiment.

To a $0{ }^{\circ} \mathrm{C}$ solution of syn-p-nitrobenzoate $(0.462 \mathrm{~g},<0.779 \mathrm{mmol})$ in $\mathrm{MeOH}(12 \mathrm{~mL})$ was added $\mathrm{K}_{2} \mathrm{CO}_{3}(0.419 \mathrm{~g}, 3.03 \mathrm{mmol})$, and the suspension was stirred for $15 \mathrm{~min}$ at $\mathrm{rt}$. After neutralization with $\mathrm{AcOH}$, the solvent was removed to give a colorless oil. The resulting oil was diluted with $\mathrm{H}_{2} \mathrm{O}(30 \mathrm{~mL})$, and extracted with EtOAc $(2 \times 50 \mathrm{~mL})$. The combined organic extracts were washed with brine $(30 \mathrm{~mL})$, dried $\left(\mathrm{MgSO}_{4}\right)$ and concentrated. Purification of the crude product by flash chromatography (25\% EtOAc/hexane) provided $\beta$-acetylenic alcohol 10 (98.6 mg, 81\% for 2 steps), of which structure was confirmed by comparison with reported spectral data ${ }^{1)}$.

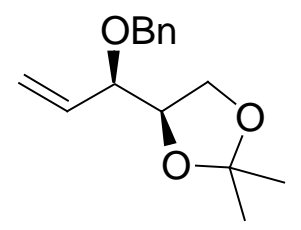

11

\section{(-)-(3R,4R)-3-Benzyloxy-4,5-isopropylidenedioxypentene (11)}

To a $0{ }^{\circ} \mathrm{C}$ suspension of $\mathrm{LiAlH}_{4}(3.89 \mathrm{~g}, 0.103 \mathrm{~mol})$ in $\mathrm{Et}_{2} \mathrm{O}(250 \mathrm{~mL})$ was added a solution of $\beta$-acetylenic alcohol $10(14.5 \mathrm{~g}, 0.0929 \mathrm{~mol})$ in $\mathrm{Et}_{2} \mathrm{O}(30 \mathrm{~mL})$. The mixture was stirred for $2 \mathrm{~h}$ at $\mathrm{rt}$, then cooled to $0{ }^{\circ} \mathrm{C}$ and $\mathrm{H}_{2} \mathrm{O}(3.89 \mathrm{~mL})$ was slowly added. After $30 \mathrm{~min}, 15 \% \mathrm{NaOH}(3.89 \mathrm{~mL})$ and $\mathrm{H}_{2} \mathrm{O}(11.7 \mathrm{~mL})$ were added and the resulting solution was stirred for an additional $10 \mathrm{~h}$ at $\mathrm{rt}$. $\mathrm{MgSO}_{4}(4 \mathrm{~g})$ was added, and the mixture was filtered through Celite and concentration to provide olefin $(12.34 \mathrm{~g})$. The crude olefin was used without further purification in a next experiment.

To a $0{ }^{\circ} \mathrm{C}$ suspension of $\mathrm{NaH}$ (3.46 g, $60 \%$ in oil, $\left.0.0864 \mathrm{mmol}\right)$ in DMF (180 mL) was added a solution of a crude olefin $(12.34 \mathrm{~g})$ in $\mathrm{DMF}(40 \mathrm{~mL})$, followed by $\mathrm{BnBr}(11.2 \mathrm{~mL}, 0.0944 \mathrm{mmol})$. 
The mixture was stirred for $1.5 \mathrm{~h}$ at $\mathrm{rt}$, and $\mathrm{H}_{2} \mathrm{O}(50 \mathrm{~mL})$ was added over $15 \mathrm{~min}$. The phases were separated and the aqueous phase was further extracted with $\mathrm{Er}_{2} \mathrm{O}(2 \times 100 \mathrm{~mL})$. The combined organic extracts were washed with brine $(50 \mathrm{~mL})$, dried $\left(\mathrm{MgSO}_{4}\right)$ and concentrated. Purification of the crude product by flash chromatography (6\% EtOAc/hexane) provided benzyl ether 11 (18.75 g, $98 \%$ for 2 steps) as a colorless oil.

Data for $11 ;[\alpha]^{28}{ }_{\mathrm{D}}=-27.46^{\circ}\left(\mathrm{c} 0.97, \mathrm{CHCl}_{3}\right)$; IR (neat) $1635 \mathrm{~cm}^{-1} ;{ }^{1} \mathrm{H} \mathrm{NMR}\left(300 \mathrm{MHz}, \mathrm{CDCD}_{3}\right)$ $\delta 1.36(\mathrm{~s}, 3 \mathrm{H}), 1.40$ (s, $3 \mathrm{H}), 3.75(\mathrm{dd}, J=8.5,6.6 \mathrm{~Hz}, 1 \mathrm{H}), 3.84(\mathrm{dd}, J=7.4,6.9 \mathrm{~Hz}$, $1 \mathrm{H}), 3.95$ (dd, $J=8.5,6.6 \mathrm{~Hz}, 1 \mathrm{H}), 4.21$ (q, $J=6.6 \mathrm{~Hz}, 1 \mathrm{H}), 4.48(\mathrm{~d}, J=12.4 \mathrm{~Hz}, 1 \mathrm{H}), 4.69$ (d, $J=$ $12.4 \mathrm{~Hz}, 1 \mathrm{H}$ ), 5.34 (ddd, $J=0.8,1.4,18.1 \mathrm{~Hz}, 1 \mathrm{H}$ ), 5.36 ( ddd, $J=0.8,1.4,9.1 \mathrm{~Hz}, 1 \mathrm{H}$ ), 5.73 (ddd, $J=7.7,11.0,18.7 \mathrm{~Hz}, 1 \mathrm{H}), 7.26-7.37(\mathrm{~m}, 5 \mathrm{H}) ;{ }^{13} \mathrm{C} \mathrm{NMR}\left(75 \mathrm{MHz}, \mathrm{CDCl}_{3}\right) \delta 138.38,134.34$, 128.34, 127.79, 127.55, 120.04, 109.68, 80.97, 77.40, 70.25, 65.68, 26.36, 25.25; LRMS m/z 233 $\left(\mathrm{M}^{+}-15\right)$; HRMS calcd for $\mathrm{C}_{14} \mathrm{H}_{17} \mathrm{O}_{3}$ 233.1177, found 233.1154; Anal. Calcd for $\mathrm{C}_{15} \mathrm{H}_{20} \mathrm{O}_{3}$ : $\mathrm{C}$, 72.55; H, 8.11. Found : C, 72.60; H, 8.08.

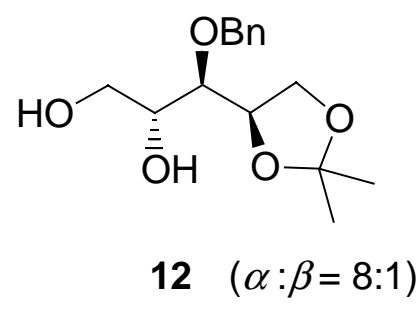

\section{(2RS,3R,4R)-3-Benzyloxy-4,5-isopropylidenedioxy-1,2-pentanediol (12)}

To a solution of olefin $11(2.43 \mathrm{~g}, 9.78 \mathrm{mmol})$ in ${ }^{t} \mathrm{BuOH}-\mathrm{H}_{2} \mathrm{O}(30 \mathrm{~mL}, 1: 1$, v/v) were added NMO $(1.72 \mathrm{~g}, 14.7 \mathrm{mmol})$ and $\mathrm{OsO}_{4}(0.124 \mathrm{~g}, 0.489 \mathrm{mmol})$. The mixture was stirred for $10 \mathrm{~h}$ at $\mathrm{rt}$, then saturated $\mathrm{Na}_{2} \mathrm{SO}_{3}$ was added. The solution was stirred for an additional $1 \mathrm{~h}$. The resulting mixture was extracted with EtOAc. The combined organic extracts were washed with brine, dried over $\mathrm{MgSO}_{4}$ and concentrated. Purification of the crude product by flash chromatography (80\% EtOAc/hexane) provided diol diastereomers $12(2.76 \mathrm{~g}, 100 \%)$ in a 8:1 ratio.

Partial data for 12 ; IR (neat) $3420 \mathrm{~cm}^{-1}$; ${ }^{1} \mathrm{H}$ NMR (300 MHz, $\mathrm{CDCl}_{3}$ ), $\delta 1.38$ (s, $3 \mathrm{H}$ ), 1.46 (s, 3 H), 2.97 (br s, 2 H), 3.59-3.69 (m, 2 H), 3.71-3.79 (m, 2 H), 3.87 (dd, J= 8.5, 7.4 Hz, 1 H), 4.04 (dd, $J=8.5,6.6 \mathrm{~Hz}, 1 \mathrm{H}), 4.32-4.43(\mathrm{~m}, 1 \mathrm{H}), 4.67(\mathrm{~d}, J=11.8 \mathrm{~Hz}, 0.1 \mathrm{H}), 4.68(\mathrm{~d}, J=11.5 \mathrm{~Hz}, 0.9 \mathrm{H})$, $4.76(\mathrm{~d}, J=11.3 \mathrm{~Hz}, 0.9 \mathrm{H}), 4.82$ (d, $J=11.5 \mathrm{~Hz}, 0.1 \mathrm{H}), 7.27-7.39$ (m, $5 \mathrm{H}) ; \mathrm{LRMS} m / z 267$ $\left(\mathrm{M}^{+}-15\right)$; HRMS calcd for $\mathrm{C}_{14} \mathrm{H}_{19} \mathrm{O}_{5} 267.1231$, found : 267.1223 .

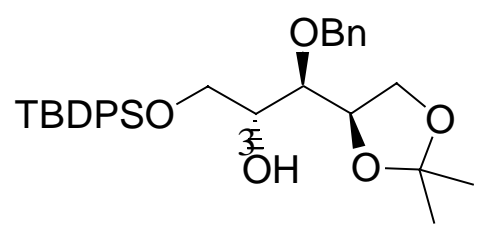


(+)-(2R,3R,4R)-3-Benzyloxy-1-tert-butyldiphenylsilyloxy-

\section{4,5-isopropylidenedioxy-2-pentol (13)}

To a solution of diol $12\left(0.475 \mathrm{~g}, 1.68 \mathrm{mmol}\right.$, a 8:1 mixture of diastereomers) in $\mathrm{CH}_{2} \mathrm{Cl}_{2}(12 \mathrm{~mL})$ were added $\mathrm{Et}_{3} \mathrm{~N}(0.305 \mathrm{~mL}, 2.18 \mathrm{mmol}), \mathrm{TBDPSCl}(0.524 \mathrm{~mL}, 2.02 \mathrm{mmol})$ and DMAP (10.3 mg, $0.084 \mathrm{mmol}$ ). The mixture was stirred for $10 \mathrm{~h}$ at rt, and quenched by $\mathrm{H}_{2} \mathrm{O}$. The resulting solution was extracted with $\mathrm{Et}_{2} \mathrm{O}$. The combined organic extracts were washed with brine, dried over $\mathrm{MgSO}_{4}$ and concentrated to provide a yellow solid. The crude product was recrystallized from $\mathrm{Et}_{2} \mathrm{O}$-hexane to yield TBDPS ether $\mathbf{1 3}(0.531 \mathrm{~g}, 61 \%)$ as a colorless powder.

Data for 13 ; mp115-117 ${ }^{\circ} \mathrm{C} ;[\alpha]^{28}{ }_{\mathrm{D}}=+6.86^{\circ}$ (c 1.02, $\mathrm{CHCl}_{3}$ ); IR (neat) $3550 \mathrm{~cm}^{-1} ;{ }^{1} \mathrm{H}$ NMR (300 $\left.\mathrm{MHz}, \mathrm{CDCl}_{3}\right) \delta 1.07(\mathrm{~s}, 9 \mathrm{H}), 1.36(\mathrm{~s}, 3 \mathrm{H}), 1.43(\mathrm{~s}, 3 \mathrm{H}), 2.71(\mathrm{~d}, J=4.7 \mathrm{~Hz}, 1 \mathrm{H}), 3.51(\mathrm{t}, J=6.0 \mathrm{~Hz}$, $1 \mathrm{H}), 3.73-3.85(\mathrm{~m}, 4 \mathrm{H}), 4.01(\mathrm{dd}, J=8.5,6.4 \mathrm{~Hz}, 1 \mathrm{H}), 4.31(\mathrm{dt}, J=7.7,6.2 \mathrm{~Hz}, 1 \mathrm{H}), 4.55(\mathrm{~d}, J=$ $11.3 \mathrm{~Hz}, 1 \mathrm{H}), 4.74$ (d, $J=11.5 \mathrm{~Hz}, 1 \mathrm{H}), 7.19-7.47$ (m, $11 \mathrm{H}), 7.62-7.66$ (m, $4 \mathrm{H}) ;{ }^{13} \mathrm{C}$ NMR $(75$ $\left.\mathrm{MHz}, \mathrm{CDCl}_{3}\right) \delta 138.38,135.78,133.18,133.12,130.06,128.48,128.14,127.99,127.79,109.01$, 79.24, 77.60, 73.94, 71.98, 66.43, 64.85, 26.89, 26.42, 25.62, 19.21; LRMS m/z $505\left(\mathrm{M}^{+}-15\right)$; HRMS calcd for $\mathrm{C}_{30} \mathrm{H}_{37} \mathrm{O}_{5} \mathrm{Si} 505.2408$, found : 505.2411; Anal. Calcd for $\mathrm{C}_{31} \mathrm{H}_{40} \mathrm{O}_{5} \mathrm{Si}: \mathrm{C}, 71.50$; H, 7.74. Found : C, $71.34 ; \mathrm{H}, 7.81$.

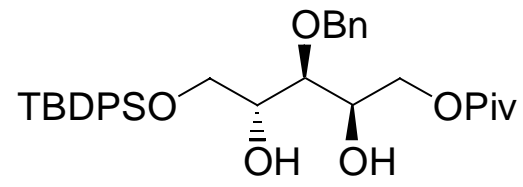

14

\section{(-)-(2R,3S,4R)-3-Benzyloxy-1-tert-butyldiphenylsilyloxy-}

\section{2,4-dihydroxypentan-5-yl pivalate (14)}

A solution of acetonide $13(6.93 \mathrm{~g}, 13.3 \mathrm{mmol})$ in $\mathrm{AcOH}-\mathrm{THF}-\mathrm{H}_{2} \mathrm{O}(40 \mathrm{~mL}, 3: 1: 1$, v/v) was stirred for $6 \mathrm{~h}$ at $55^{\circ} \mathrm{C}$. The solution was cooled to $\mathrm{rt}$, and then poured into saturated $\mathrm{NaHCO}_{3}$. The resulting solution was extracted with EtOAc. The combined organic extracts were washed with brine, dried over $\mathrm{MgSO}_{4}$ and concentrated. Purification of the crude product by flash chromatography $(80 \%$ EtOAc/hexane) provided a triol $(6.28 \mathrm{~g}, 98 \%)$ as a colorless oil.

Data for the triol; $[\alpha]^{26}{ }_{\mathrm{D}}=-5.00^{\circ}\left(\mathrm{c} 1.16, \mathrm{CHCl}_{3}\right)$; IR (neat) $3400 \mathrm{~cm}^{-1} ;{ }^{1} \mathrm{H} \mathrm{NMR}(300 \mathrm{MHz}$, $\left.\mathrm{CDCl}_{3}\right) \delta 1.08(\mathrm{~s}, 9 \mathrm{H}), 2.22($ br s, $1 \mathrm{H}), 2.92-2.96(\mathrm{~m}, 2 \mathrm{H}), 3.59(\mathrm{dd}, J=3.2,6.4 \mathrm{~Hz}, 1 \mathrm{H})$, 3.63-3.73 (m, 2 H), 3.77 (dd, $J=6.1,10.4$ Hz, 1 H), 3.85 (dd, J= 4.4, 10.4 Hz, 1 H), 3.88-3.97 (m, $2 \mathrm{H}), 4.51(\mathrm{~d}, J=11.3 \mathrm{~Hz}, 1 \mathrm{H}), 4.56(\mathrm{~d}, J=11.3 \mathrm{~Hz}, 1 \mathrm{H}), 7.16-7.21(\mathrm{~m}, 2 \mathrm{H}), 7.26-7.30(\mathrm{~m}, 3 \mathrm{H})$, 7.35-7.48 (m, $6 \mathrm{H}), 7.63-7.66(\mathrm{~m}, 4 \mathrm{H}) ;{ }^{13} \mathrm{C} \mathrm{NMR}\left(75 \mathrm{MHz}, \mathrm{CDCl}_{3}\right) \delta 137.60,135.72,135.69$, 133.08, 13 2.99, 130.03, 128.57, 128.20, 128.10, 127.96, 78.07, 73.44, 71.62, 64.83, 64.04, 26.85, 
19.14; LRMS m/z $423\left(\mathrm{M}^{+}-57\right)$; HRMS calcd for $\mathrm{C}_{24} \mathrm{H}_{27} \mathrm{O}_{5} \mathrm{Si}$ 423.1626, found : 423.1645; Anal. Calcd for $\mathrm{C}_{28} \mathrm{H}_{36} \mathrm{O}_{5} \mathrm{Si}: \mathrm{C}, 69.96$; H, 7.54. Found : C, 69.99 ; H, 7.63.

To a solution of the triol $(1.21 \mathrm{~g}, 2.51 \mathrm{mmol})$ in $\mathrm{CH}_{2} \mathrm{Cl}_{2}(10 \mathrm{~mL})$ were added pyridine $(2 \mathrm{~mL}, 24.7$ $\mathrm{mmol})$ and $\mathrm{PivCl}(0.324 \mathrm{~mL}, 2.63 \mathrm{mmol})$. The mixture was stirred for $10 \mathrm{~h}$ at $\mathrm{rt}$. After the solvent was removed, the resulting crude oil was purified by flash chromatography (20\% EtOAc/hexane) to provide pivalate $\mathbf{1 4}(1.27 \mathrm{~g}, 89 \%)$ as a colorless oil.

Data for $14 ;[\alpha]^{20}{ }_{\mathrm{D}}=-4.50^{\circ}$ (c $1.20, \mathrm{CHCl}_{3}$ ); IR (neat) $3450,1725 \mathrm{~cm}^{-1} ;{ }^{1} \mathrm{H} \mathrm{NMR}(300 \mathrm{MHz}$, $\left.\mathrm{CDCl}_{3}\right) \delta 1.08(\mathrm{~s}, 9 \mathrm{H}), 1.21(\mathrm{~s}, 9 \mathrm{H}), 2.79(\mathrm{br} \mathrm{s}, 2 \mathrm{H}), 3.58(\mathrm{dd}, J=1.9,7.1 \mathrm{~Hz}, 1 \mathrm{H}), 3.78(\mathrm{dd}, J=$ 5.5, $10.4 \mathrm{~Hz}, 1 \mathrm{H}), 3.87$ (dd, J= 3.8, $10.4 \mathrm{~Hz}, 1 \mathrm{H}), 3.90-3.97(\mathrm{~m}, 1 \mathrm{H}), 4.12(\mathrm{dd}, J=5.5,12.7 \mathrm{~Hz}, 1$ H), 4.11-4.15 (m, 1 H), 4.25 (dd, J= 8.8, 12.6 Hz, 1 H), 4.53 (s, 2 H), 7.14-7.18 (m, 2 H), 7.26-7.29 $(\mathrm{m}, 3 \mathrm{H}), 7.32-7.48(\mathrm{~m}, 6 \mathrm{H}), 7.63-7.66(\mathrm{~m}, 4 \mathrm{H}) ;{ }^{13} \mathrm{C} \mathrm{NMR}\left(75 \mathrm{MHz}, \mathrm{CDCl}_{3}\right) \delta 178.46,137.54$, 135.64, 135.61, 132.97, 132.83, 129.95, 128.45, 128.05, 127.96, 127.88, 77.22, 73.59, 71.36, 69.10, 64.92, 64.67, 38.61, 27.05, 26.76, 19.06; LRMS m/z $489\left(\mathrm{M}^{+}-75\right)$; HRMS calcd for $\mathrm{C}_{29} \mathrm{H}_{33} \mathrm{O}_{5} \mathrm{Si}$ 489.2095, found : 489.2127; Anal. Calcd for $\mathrm{C}_{33} \mathrm{H}_{44} \mathrm{O}_{6} \mathrm{Si}: \mathrm{C}, 70.17$; H, 7.85. Found : C, $70.00 ; \mathrm{H}, 7.81$.

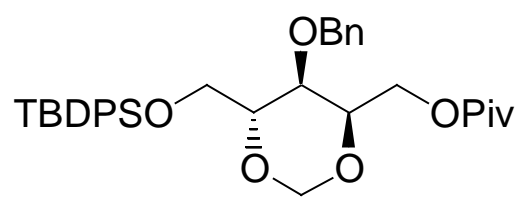

15

(+)-(2S,3R,4R)-3-Benzyloxy-5-tert-butyldiphenylsilyloxy-2,4-methylenedioxypentanal (15)

To a solution of diol $14(0.340 \mathrm{~g}, 0.559 \mathrm{mmol})$ in $\mathrm{CH}_{2} \mathrm{Cl}_{2}(60 \mathrm{~mL})$ was added freshly distilled dimethoxymethane $(12 \mathrm{~mL})$ followed by $\mathrm{P}_{2} \mathrm{O}_{5}(3.4 \mathrm{~g})$. The mixture was vigorously stirred for $1.5 \mathrm{~h}$, and poured into saturated $\mathrm{NaHCO}_{3}$ at $0{ }^{\circ} \mathrm{C}$. The phases were separated and the aqueous phase was further extracted with $\mathrm{Et}_{2} \mathrm{O}$. The combined organic extracts were washed with brine, dried over $\mathrm{MgSO}_{4}$ and concentrated. Purification of the crude product by flash chromatography (9\% EtOAc/hexane) provided a methylene acetal $15(0.303 \mathrm{~g}, 88 \%)$ as a colorless oil.

Data for $15 ;[\alpha]^{28}{ }_{\mathrm{D}}=+12.82^{\circ}$ (c $0.95, \mathrm{CHCl}_{3}$ ); IR (neat) $1730 \mathrm{~cm}^{-1} ;{ }^{1} \mathrm{H} \mathrm{NMR}\left(300 \mathrm{MHz}, \mathrm{CDCl}_{3}\right)$ $\delta 1.06(\mathrm{~s}, 9 \mathrm{H}), 1.19$ (s, $9 \mathrm{H}), 3.76(\mathrm{dd}, J=3.8,4.7 \mathrm{~Hz}, 1 \mathrm{H}), 3.85-3.97(\mathrm{~m}, 3 \mathrm{H}), 4.17-4.24(\mathrm{~m}, 2 \mathrm{H})$, 4.50 (dd, $J=9.1,12.9 \mathrm{~Hz}, 1 \mathrm{H}), 4.53(\mathrm{~d}, J=11.8 \mathrm{~Hz}, 1 \mathrm{H}), 4.64(\mathrm{~d}, J=11.8 \mathrm{~Hz}, 1 \mathrm{H}), 4.86$ (d, $J=6.3$ $\mathrm{Hz}, 1 \mathrm{H}), 4.94(\mathrm{~d}, J=6.3 \mathrm{~Hz}, 1 \mathrm{H}), 7.26-7.44(\mathrm{~m}, 11 \mathrm{H}), 7.64-7.68(\mathrm{~m}, 4 \mathrm{H}) ;{ }^{13} \mathrm{C} \mathrm{NMR}(75 \mathrm{MHz}$, $\left.\mathrm{CDCl}_{3}\right) \delta 178.56,137.71,135.84,135.76,133.23,133.12,130.03,128.64,128.14,128.11,127.96$, 88.27, 75.22, 72.42, 72.18, 70.69, 62.63, 61.63, 38.75, 27.15, 26.83, 19.21; LRMS m/z 519 $\left(\mathrm{M}^{+}-57\right)$; HRMS calcd for $\mathrm{C}_{30} \mathrm{H}_{35} \mathrm{O}_{6} \mathrm{Si}$ 519.2200, found : 519.2200; Anal. Calcd for $\mathrm{C}_{34} \mathrm{H}_{44} \mathrm{O}_{6} \mathrm{Si}$ : C,70.79; H, 7.68. Found : C, $70.62 ; \mathrm{H}, 7.67$.

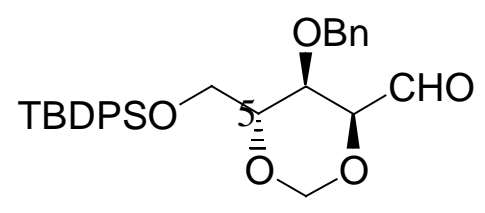


To a $0{ }^{\circ} \mathrm{C}$ solution of $\mathbf{1 5}(1.22 \mathrm{~g}, 2.12 \mathrm{mmol})$ in THF $(13 \mathrm{~mL})$ was added DIBAL-H $(4.96 \mathrm{~mL}$, $4.66 \mathrm{mmol})$ dropwise. The solution was stirred for $1 \mathrm{~h}$ at that temperature. $\mathrm{H}_{2} \mathrm{O}(5 \mathrm{~mL})$ was added

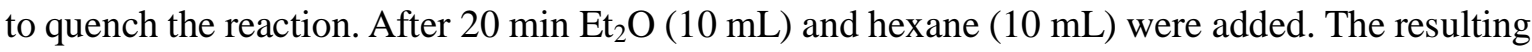
mixture was allowed to warm to $\mathrm{rt}$ and stirred for $10 \mathrm{~h}$, then dried $\left(\mathrm{MgSO}_{4}\right)$ and filterd through Celite. The filtrate was concentrated to afford a crude oil. Purification of the crude product by flash chromatography (33\% EtOAc/hexane) provided an alcohol (1.04 g, 99\%) as a colorless oil.

Data for the alcohol; $[\alpha]^{27}=+0.75^{\circ}\left(\mathrm{c} 1.05, \mathrm{CHCl}_{3}\right)$; IR (neat) $3425 \mathrm{~cm}^{-1} ;{ }^{1} \mathrm{H} \mathrm{NMR}(300 \mathrm{MHz}$, $\left.\mathrm{CDCl}_{3}\right) \delta 1.08(\mathrm{~s}, 9 \mathrm{H}), 1.83-1.85(\mathrm{~m}, 1 \mathrm{H}), 3.62-3.71$ (m, $\left.2 \mathrm{H}\right), 3.89-3.96(\mathrm{~m}, 4 \mathrm{H}), 3.98-4.01$ (m, 1 H), $4.46(\mathrm{~d}, J=11.5 \mathrm{~Hz}, 1 \mathrm{H}), 4.67(\mathrm{~d}, J=11.8 \mathrm{~Hz}, 1 \mathrm{H}), 4.83(\mathrm{~d}, J=6.3 \mathrm{~Hz}, 1 \mathrm{H}), 4.91(\mathrm{~d}, J=6.3 \mathrm{~Hz}$, $1 \mathrm{H}), 7.25-7.48(\mathrm{~m}, 11 \mathrm{H}), 7.64-7.68(\mathrm{~m}, 4 \mathrm{H}) ;{ }^{13} \mathrm{C} \mathrm{NMR}\left(75 \mathrm{MHz}, \mathrm{CDCl}_{3}\right) \delta 137.53,135.78$, 135.72, 133.09, 129.99, 128.66, 128.25, 128.20, 127.93, 127.90, 88.23, 75.04, 74.41, 71.97, 70.83, 62.18, 61.01, 26.82, 19.15 ; LRMS m/z $435\left(\mathrm{M}^{+}-57\right)$; HRMS calcd for $\mathrm{C}_{25} \mathrm{H}_{27} \mathrm{O}_{5} \mathrm{Si}$ 435.1626, found : 435.1610 ; Anal. Calcd for $\mathrm{C}_{29} \mathrm{H}_{36} \mathrm{O}_{5} \mathrm{Si}$ : C,70.69 ; H, 7.36. Found : C, 70.83 ; H, 7.51.

To a $-78{ }^{\circ} \mathrm{C}$ solution of $(\mathrm{COCl})_{2}(0.080 \mathrm{~mL}, 0.917 \mathrm{mmol})$ in $\mathrm{CH}_{2} \mathrm{Cl}_{2}(5 \mathrm{~mL})$ was added a solution of DMSO $(0.141 \mathrm{~mL}, 1.99 \mathrm{mmol})$ in $\mathrm{CH}_{2} \mathrm{Cl}_{2}(3 \mathrm{~mL})$ dropwise over $10 \mathrm{~min}$. The mixture was stirred for $30 \mathrm{~min}$, then a solution of the above alcohol $(0.377 \mathrm{~g}, 0.765 \mathrm{mmol})$ in $\mathrm{CH}_{2} \mathrm{Cl}_{2}(3 \mathrm{~mL})$ was added dropwise. The mixture was stirred for $1 \mathrm{~h}$ at $-78{ }^{\circ} \mathrm{C}$, then $\mathrm{Et}_{3} \mathrm{~N}(0.553 \mathrm{~mL}, 3.97 \mathrm{mmol})$ was added. The solution was stirred for $20 \mathrm{~min}$ at $-78{ }^{\circ} \mathrm{C}$, then warmed to $-30{ }^{\circ} \mathrm{C}$ and quenched by $\mathrm{H}_{2} \mathrm{O}(3 \mathrm{~mL})$. The phases were separated and the aqueous phase was further extracted with $\mathrm{Et}_{2} \mathrm{O}$. The combined organic extracts were washed with brine, dried over $\mathrm{MgSO}_{4}$ and concentrated, producing crude aldehyde 16 ( $0.38 \mathrm{~g})$. Due to the instability of the crude aldehyde 16, it was immediately used without further purification.
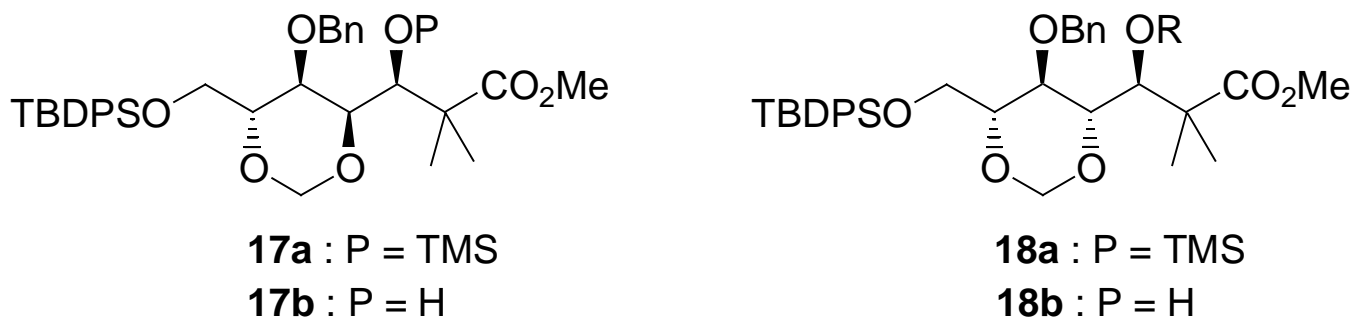

(+)-Methyl $(3 S, 4 R, 5 R, 6 S)$-5-Benzyloxy-7-tert-butyldiphenylsilyloxy-2,2-dimethyl4,6-methylenedioxy-3-trimethylsilyloxyheptanoate (17a)

(-)-Methyl (3S,4R,5R,6R)-5-Benzyloxy-7-tert-butyldiphenylsilyloxy-2,2-dimethyl3-hydroxy-4,6-methylenedioxy-heptanoate (17b) 


\section{(-)-Methyl (3S,4R,5R,6R)-5-Benzyloxy-7-tert-butyldiphenylsilyloxy-2,2-dimethyl- 4,6-methylenedioxy-3-trimethylsilyloxyheptanoate (18a)}

\section{(-)-Methyl $(3 S, 4 R, 5 R, 6 S)-5$-Benzyloxy-7-tert-butyldiphenylsilyloxy-2,2-dimethyl- 3-hydroxy-4,6-methylenedioxyheptanoate (18b)}

(entry 3)

To a water bath cooled suspention of $\mathrm{Yb}(\mathrm{OTf})_{3}(47 \mathrm{mg}, 0.076 \mathrm{mmol})$ in $\mathrm{CH}_{2} \mathrm{Cl}_{2}(30 \mathrm{~mL})$ was added a mixture of the crude aldehyde $\mathbf{1 6}(0.38 \mathrm{~g})$ and methyl trimethylsilyl dimethylketene acetal (0.39 mL, $1.92 \mathrm{mmol})$ in $\mathrm{CH}_{2} \mathrm{Cl}_{2}(10 \mathrm{~mL})$ dropwise. The mixture was stirred for $48 \mathrm{~h}$ at $\mathrm{rt}$ and saturated $\mathrm{NaHCO}_{3}(10 \mathrm{~mL})$ was added. The phases were separated and the aqueous phase was further extracted with EtOAc. The combined organic extracts were washed with brine, dried over $\mathrm{MgSO}_{4}$ and concentrated. The crude product was purified by flash chromatography. Elution with a 10:1 mixture of hexane-EtOAc afforded aldol 17a and 18a (17a: $0.261 \mathrm{~g}, 51 \%$ for 2 steps; 18a: $0.125 \mathrm{~g}, 25 \%$ for 2 steps) as a colorless oil. Elution with a $6: 1$ mixture of hexane-EtOAc afforded aldol 17b and 18b (17b: $35.7 \mathrm{mg}$, 8\% for 2 steps; 18b: $24.0 \mathrm{mg}, 5 \%$ for 2 steps) as a colorless oil. Data for 17a ; $[\alpha]^{27}{ }_{\mathrm{D}}=+19.09^{\circ}\left(\mathrm{c} 0.54, \mathrm{CHCl}_{3}\right)$; IR (neat) $1735 \mathrm{~cm}^{-1} ;{ }^{1} \mathrm{H}$ NMR $(500 \mathrm{MHz}$, $\left.\mathrm{CDCl}_{3}\right) \delta 0.06(\mathrm{~s}, 9 \mathrm{H}), 1.08(\mathrm{~s}, 9 \mathrm{H}), 1.13(\mathrm{~s}, 3 \mathrm{H}), 1.23(\mathrm{~s}, 3 \mathrm{H}), 3.60(\mathrm{~s}, 3 \mathrm{H}), 3.82(\mathrm{dd}, J=4.4,5.5$ $\mathrm{Hz}, 1 \mathrm{H}), 3.87(\mathrm{dd}, J=4.8,11.0 \mathrm{~Hz}, 1 \mathrm{H}), 3.89$ (t, $J=4.8 \mathrm{~Hz}, 1 \mathrm{H}), 3.93(\mathrm{dd}, J=5.1,11.0 \mathrm{~Hz}$, $1 \mathrm{H}), 4.23(\mathrm{q}, J=5.3 \mathrm{~Hz}, 1 \mathrm{H}), 4.45(\mathrm{~d}, J=5.1 \mathrm{~Hz}, 1 \mathrm{H}), 4.50(\mathrm{~d}, J=11.7 \mathrm{~Hz}, 1 \mathrm{H}), 4.64$ (d, $J=11.7$ $\mathrm{Hz}, 1 \mathrm{H}), 4.77$ (d, J=5.9 Hz, $1 \mathrm{H}), 5.15$ (d, J=5.9 Hz, $1 \mathrm{H}), 7.24-7.44(\mathrm{~m}, 11 \mathrm{H}), 7.67-7.71$ (m, 4 $\mathrm{H}) ;{ }^{13} \mathrm{C}$ NMR $\left(125 \mathrm{MHz}, \mathrm{CDCl}_{3}\right) \delta 177.48,138.18,135.82,135.70,133.40,133.21,129.86$, $128.42,127.96,127.85,127.82,127.75,89.94,75.89,74.50,74.27,71.93,71.88,62.68,51.86$, 47.71, 26.96, 21.89, 21.87, 19.36, 0.87; LRMS m/z $649\left(\mathrm{M}^{+}-15\right)$; HRMS calcd for $\mathrm{C}_{36} \mathrm{H}_{49} \mathrm{O}_{7} \mathrm{Si}_{2}$ 649.3014, found : 649.3003 ; Anal. Calcd for $\mathrm{C}_{37} \mathrm{H}_{52} \mathrm{O}_{7} \mathrm{Si}_{2}$ : C,66.82; H, 7.88. Found : C, $66.84 ; \mathrm{H}$, 7.98 .

Data for 17b ; $[\alpha]^{27}{ }_{\mathrm{D}}=-6.03^{\circ}\left(\mathrm{c} 1.03, \mathrm{CHCl}_{3}\right)$; IR (neat) $3500,1720 \mathrm{~cm}^{-1} ;{ }^{1} \mathrm{H} \mathrm{NMR}(300 \mathrm{MHz}$, $\left.\mathrm{CDCl}_{3}\right) \delta 1.08(\mathrm{~s}, 9 \mathrm{H}), 1.17(\mathrm{~s}, 3 \mathrm{H}), 1.19(\mathrm{~s}, 3 \mathrm{H}), 3.50(\mathrm{~d}, J=3.8 \mathrm{~Hz}, 1 \mathrm{H}), 3.63(\mathrm{~s}, 3 \mathrm{H}), 3.74(\mathrm{t}$, $J=3.3 \mathrm{~Hz}, 1 \mathrm{H}), 3.84-3.91(\mathrm{~m}, 4 \mathrm{H}), 4.16-4.21(\mathrm{~m} 1 \mathrm{H}), 4.51$ (d, $J=11.5 \mathrm{~Hz}, 1 \mathrm{H}), 4.72(\mathrm{~d}, J=11.8$ $\mathrm{Hz}, 1 \mathrm{H}), 4.86(\mathrm{~d}, J=5.8 \mathrm{~Hz}, 1 \mathrm{H}), 5.00$ (d, $J=5.8 \mathrm{~Hz}, 1 \mathrm{H}), 7.27-7.48(\mathrm{~m}, 11 \mathrm{H}), 7.64-7.67$ (m, 4 $\mathrm{H}) ;{ }^{13} \mathrm{C} \mathrm{NMR}\left(75 \mathrm{MHz}, \mathrm{CDCl}_{3}\right) \delta 177.71,137.39,135.70,135.66,133.02,132.97,130.04,128.64$, $128.29,128.17,127.95,89.40,76.19,74.85,74.47,72.21,71.65,62.43,51.84,46.36,26.79,21.78$, 21.59, 19.14; LRMS $m / z 535\left(\mathrm{M}^{+}-57\right)$; HRMS calcd for $\mathrm{C}_{30} \mathrm{H}_{35} \mathrm{O}_{7} \mathrm{Si} 535.2150$, found : 535.2147 ; Anal. Calcd for $\mathrm{C}_{34} \mathrm{H}_{44} \mathrm{O}_{7} \mathrm{Si}: \mathrm{C}, 68.88 ; \mathrm{H}, 7.48$. Found : C, $68.79 ; \mathrm{H}, 7.46$.

Data for 18a ; $[\alpha]^{27}{ }_{D}=-1.64^{\circ}\left(\mathrm{c} 1.68, \mathrm{CHCl}_{3}\right)$; IR (neat) 2932, 1732, 1252, 1113, 1042, 843, 735, $702 \mathrm{~cm}^{-1} ;{ }^{1} \mathrm{H}$ NMR $\left(500 \mathrm{MHz}, \mathrm{CDCl}_{3}\right) \delta 0.21(\mathrm{~s}, 9 \mathrm{H}), 1.07(\mathrm{~s}, 9 \mathrm{H}), 1.20(\mathrm{~s}, 3 \mathrm{H}), 1.28(\mathrm{~s}, 3 \mathrm{H})$, $3.41(\mathrm{td}, J=2.4,7.2 \mathrm{~Hz}, 1 \mathrm{H}), 3.45(\mathrm{~d}, J=7.6 \mathrm{~Hz}, 1 \mathrm{H}), 3.62(\mathrm{~s}, 3 \mathrm{H}), 3.82(\mathrm{t}, J=7.2 \mathrm{~Hz}, 1 \mathrm{H})$, 3.92-3.93 (m, $2 \mathrm{H}), 4.42$ (s, $1 \mathrm{H}), 4.59$ (d, $J=4.8 \mathrm{~Hz}, 1 \mathrm{H}), 4.72$ (d, $J=3.6 \mathrm{~Hz}, 1 \mathrm{H}), 5.15$ (d, $J=4.8$ 
$\mathrm{Hz}, 1 \mathrm{H}), 7.19-7.21(\mathrm{~m}, 2 \mathrm{H}), 7.27-7.41(\mathrm{~m}, 9 \mathrm{H}), 7.67-7.70(\mathrm{~m}, 2 \mathrm{H}), 7.72-7.74(\mathrm{~m}, 2 \mathrm{H}) ;{ }^{13} \mathrm{C}$ NMR $\left(125 \mathrm{MHz}, \mathrm{CDCl}_{3}\right) \delta 177.3,137.9,135.9,135.7,133.5,132.9,129.7,129.6,128.4,127.7$, 127.6, 127.3, 92.8, 81.8, 79.2, 74.0, 73.5, 69.8, 63.4, 51.8, 48.2, 26.9, 21.9,19.3, 1.23; LRMS $\mathrm{m} / \mathrm{z}$ $607\left(\mathrm{M}^{+}-57\right)$; HRMS calcd for $\mathrm{C}_{33} \mathrm{H}_{43} \mathrm{O}_{7} \mathrm{Si}_{2}$ 607.2545, found : 607.2552.

Data for 18b; $[\alpha]^{28}{ }_{\mathrm{D}}=-3.09^{\circ}\left(\mathrm{c} 0.34, \mathrm{CHCl}_{3}\right)$; IR (neat) $3452,1732,1084,1040,741,702 \mathrm{~cm}^{-1}$; ${ }^{1} \mathrm{H}$ NMR $\left(300 \mathrm{MHz}, \mathrm{CDCl}_{3}\right) \delta 1.07(\mathrm{~s}, 9 \mathrm{H}), 1.20(\mathrm{~s}, 3 \mathrm{H}), 1.34(\mathrm{~s}, 3 \mathrm{H}), 3.42(\mathrm{~d}, J=10.9 \mathrm{~Hz}, 1 \mathrm{H})$, $3.74(\mathrm{~d}, J=10.9 \mathrm{~Hz}, 1 \mathrm{H}), 3.48(\mathrm{td}, J=2.4,9.0 \mathrm{~Hz}, 1 \mathrm{H}), 3.52$ (d, $J=9.3 \mathrm{~Hz}, 1 \mathrm{H}), 3.67$ (s, $3 \mathrm{H})$, 3.89-3.97 (m, $3 \mathrm{H}), 4.59$ (d, $J=5.4 \mathrm{~Hz}, 1 \mathrm{H}), 4.61$ (d, $J=10.2 \mathrm{~Hz}, 1 \mathrm{H}), 4.70$ (d, $J=10.2 \mathrm{~Hz}, 1 \mathrm{H})$, 4.99 (d, J=5.8 Hz, $1 \mathrm{H}), 7.16-7.19$ (m, $2 \mathrm{H}), 7.27-7.45(\mathrm{~m}, 9 \mathrm{H}), 7.64-7.73(\mathrm{~m}, 4 \mathrm{H}) ;{ }^{13} \mathrm{C} \mathrm{NMR}(75$ $\left.\mathrm{MHz}, \mathrm{CDCl}_{3}\right) \delta 177.7,138.0,135.7,133.3,129.7,129.7,128.5,127.9,127.8,127.6,92.6, \quad 81.5$, 78.8, 74.9, 74.7, 69.4, 65.8, 63.2, 51.8, 44.5, 26.7, 24.3, 21.7, 19.2, 15.1; LRMS m/z $535\left(\mathrm{M}^{+}-57\right)$; HRMS calcd for $\mathrm{C}_{30} \mathrm{H}_{35} \mathrm{O}_{7} \mathrm{Si} 535.2150$, found : 535.2186.

(entry 1 )

To a $-78{ }^{\circ} \mathrm{C}$ solution of crude aldehyde $16(53.0 \mathrm{mg})$ in $\mathrm{CH}_{2} \mathrm{Cl}_{2}(1 \mathrm{~mL})$ was added $\mathrm{TiCl}_{4}(0.0180$ $\mathrm{mL}, 0.162 \mathrm{mmol})$, followed by methyl trimethylsilyl dimethylketene acetal $(0.0330 \mathrm{~mL}, 0.162$ $\mathrm{mmol})$ in $\mathrm{CH}_{2} \mathrm{Cl}_{2}(1 \mathrm{~mL})$ dropwise. The mixture was stirred for $1 \mathrm{~h}$ at $-78{ }^{\circ} \mathrm{C}$ and quenched by $\mathrm{H}_{2} \mathrm{O}$. The phases were separated and the aqueous phase was further extracted with $\mathrm{Et}_{2} \mathrm{O}$. The combined organic extracts were washed with brine, dried over $\mathrm{MgSO}_{4}$ and concentrated. Purification of the crude product by flash chromatography (20\% EtOAc/hexane) provided aldol 17b (40.4 mg, 63\% for 2 steps).

(entry 5)

To a water bath cooled suspension of $\mathrm{Yb}(\mathrm{OTf})_{3}(15 \mathrm{mg}, 0.025 \mathrm{mmol})$ and TMSCl $(0.030 \mathrm{~mL}, 0.25$ $\mathrm{mmol})$ in $\mathrm{CH}_{2} \mathrm{Cl}_{2}(20 \mathrm{~mL})$ was added a mixture of the crude aldehyde $16(0.122 \mathrm{~g})$ and methyl trimethylsilyl dimethylketene acetal $(0.125 \mathrm{~mL}, 0.618 \mathrm{mmol})$ in $\mathrm{CH}_{2} \mathrm{Cl}_{2}(5 \mathrm{~mL})$ dropwise. The mixture was stirred for $24 \mathrm{~h}$ at $\mathrm{rt}$ and quenched by saturated $\mathrm{NaHCO}_{3}(10 \mathrm{~mL})$. The phases were separated and the aqueous phase was further extracted with EtOAc. The combined organic extracts were washed with brine, dried over $\mathrm{MgSO}_{4}$ and concentrated. The crude product was purified by flash chromatography. Elution with a 10:1 mixture of hexane-EtOAc afforded aldol 17a $(0.130 \mathrm{~g}$, $79 \%$ for 2 steps) as a colorless oil. Elution with a 4:1 mixture of hexane-EtOAc afforded aldol 17b (15.2 $\mathrm{mg}, 10 \%$ for 2 steps) as a colorless oil.

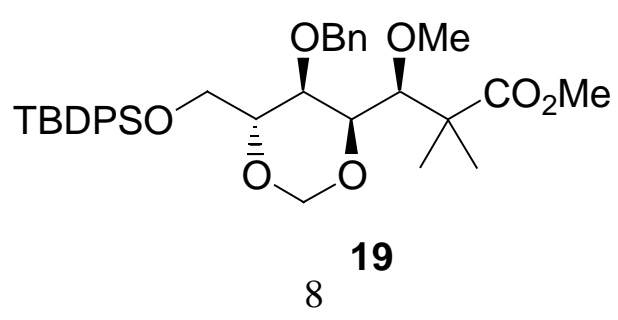




\section{(+)-Methyl (3S,4R,5R,6R)-5-Benzyloxy-7-tert-butyldiphenylsilyloxy-2,2-dimethyl-}

\section{3-methoxy-4,6-methylenedioxy-heptanoate (19)}

To a solution of a crude mixture of $\mathbf{1 7} \mathbf{a}$ and $\mathbf{1 7} \mathbf{b}(16 \mathrm{mg})$ in $\mathrm{MeOH}(1 \mathrm{~mL})$ was added CSA (1.0 $\mathrm{mg}$, cat.). The mixture was stirred for $15 \mathrm{~min}$ at $\mathrm{rt}$, then quenched by saturated $\mathrm{NaHCO}_{3}(1 \mathrm{~mL})$. The phases were separated and the aqueous phase was extracted with EtOAc. The combined organic extracts were washed with brine, dried over $\mathrm{MgSO}_{4}$ and concentrated. Purification of the crude product by flash chromatography (14\% EtOAc/hexane) provided alcohol 17b (11.9 mg, $84 \%$ for 3 steps).

To a $0{ }^{\circ} \mathrm{C}$ suspension of $\mathrm{NaH}(53.7 \mathrm{mg}, 1.34 \mathrm{mmol})$ in THF $(13 \mathrm{~mL})$ was added a solution of alcohol 17b $(0.531 \mathrm{~g}, 0.895 \mathrm{mmol})$ in THF $(2 \mathrm{~mL})$ dropwise. The mixture was stirred for $30 \mathrm{~min}$ at $0{ }^{\circ} \mathrm{C}$, then warmed to $\mathrm{rt}$ and stirred for $1 \mathrm{~h}$. After the solution was cooled to $0{ }^{\circ} \mathrm{C}, \mathrm{MeI}(0.111 \mathrm{~mL}$, $1.79 \mathrm{mmol}$ ) was added and the mixture was stirred for $30 \mathrm{~min}$ at $0{ }^{\circ} \mathrm{C}$. The resulting mixture was allowed to warm to $\mathrm{rt}$ and stirred for an additional $4 \mathrm{~h}$, then poured into saturated $\mathrm{NH}_{4} \mathrm{Cl}$ at $0{ }^{\circ} \mathrm{C}$. The phases were separated and the aqueous phase was extracted with $\mathrm{Et}_{2} \mathrm{O}$. The combined organic extracts were washed with brine, dried over $\mathrm{MgSO}_{4}$ and concentrated. Purification of the crude product by flash chromatography (13\% EtOAc/hexane) provided methyl ether 19 (0.519 mg, $95 \%)$.

Data for $19 ;[\alpha]^{20}{ }_{\mathrm{D}}=+28.18^{\circ}\left(\mathrm{c} 0.85, \mathrm{CHCl}_{3}\right)$; IR (neat) $1720 \mathrm{~cm}^{-1} ;{ }^{1} \mathrm{H} \mathrm{NMR}\left(300 \mathrm{MHz}, \mathrm{CDCl}_{3}\right)$ $\delta 1.08(\mathrm{~s}, 9 \mathrm{H}), 1.17(\mathrm{~s}, 3 \mathrm{H}), 1.26(\mathrm{~s}, 3 \mathrm{H}), 3.38(\mathrm{~s}, 3 \mathrm{H}), 3.65(\mathrm{~s}, 3 \mathrm{H}), 3.83$ (d, J=2.7 Hz, $1 \mathrm{H})$, 3.86-3.93 (m, $3 \mathrm{H}), 4.06-4.13(\mathrm{~m}, 2 \mathrm{H}), 4.55(\mathrm{~d}, J=11.5 \mathrm{~Hz}, 1 \mathrm{H}), 4.62(\mathrm{~d}, J=11.8 \mathrm{~Hz}, 1 \mathrm{H}), 4.74(\mathrm{~d}$, $J=5.5 \mathrm{~Hz}, 1 \mathrm{H}), 5.26(\mathrm{~d}, J=5.5 \mathrm{~Hz}, 1 \mathrm{H}), 7.26-7.42(\mathrm{~m}, 11 \mathrm{H}), 7.67-7.73(\mathrm{~m}, 4 \mathrm{H})$;

${ }^{13} \mathrm{C} \mathrm{NMR}\left(75 \mathrm{MHz}, \mathrm{CDCl}_{3}\right) \delta 177.62,138.07,135.92,135.75,133.65,133.37,129.83,128.58$, 128.08, 127.96, 127.84, 127.79, 90.01, 84.93, 75.40, 72.68, 72.58, 71.56, 63.30, 60.54, 51.81, 47.28, 26.83, 21.91, 21.76, 19.27 ; LRMS m/z $457\left(\mathrm{M}^{+}-149\right)$; HRMS calcd for $\mathrm{C}_{24} \mathrm{H}_{29} \mathrm{O}_{7} \mathrm{Si}$ 457.1681, found : 457.1666; Anal. Calcd for $\mathrm{C}_{35} \mathrm{H}_{46} \mathrm{O}_{7} \mathrm{Si}: \mathrm{C}, 69.27$; H, 7.64. Found : C, 69.27 ; H, 7.77.

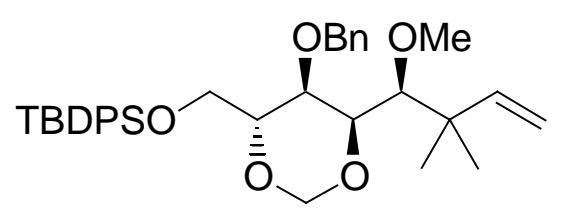

20

\section{(+)-(4S,5R,6R,7R)-6-Benzyloxy-8-tert-butyldiphenylsilyloxy-3,3-dimethyl-}

\section{4-methoxy-5,7-methylenedioxyoct-1-ene (20)}

To a $0{ }^{\circ} \mathrm{C}$ solution of ester $19(0.0980 \mathrm{~g}, 0.162 \mathrm{mmol})$ in THF $(5 \mathrm{~mL})$ was added DIBAL-H $(0.440$ $\mathrm{mL}, 0.404 \mathrm{mmol})$ dropwise. The solution was stirred for $1 \mathrm{~h}$ at that temperature. $\mathrm{H}_{2} \mathrm{O}(0.44 \mathrm{~mL})$ was added to quench the reaction. After $20 \mathrm{~min}, \mathrm{Et}_{2} \mathrm{O}(5 \mathrm{~mL})$ and hexane $(5 \mathrm{~mL})$ were added. The resulting mixture was allowed to warm to $\mathrm{rt}$ and stirred for $1 \mathrm{~h}$, then dried $\left(\mathrm{MgSO}_{4}\right)$ and filterd 
through Celite. The filtrate was concentrated to afford a crude solid. The crude product was recrystallized from $\mathrm{Et}_{2} \mathrm{O}$-hexane to provided an alcohol $(0.0934 \mathrm{~g}, 100 \%)$ as colorless plates.

Data for the alcohol : $\mathrm{mp} 108-109{ }^{\circ} \mathrm{C} ;[\alpha]^{27}{ }_{\mathrm{D}}=+30.36^{\circ}\left(\mathrm{c} 1.05, \mathrm{CHCl}_{3}\right)$; IR (neat) $3450 \mathrm{~cm}^{-1} ;{ }^{1} \mathrm{H}$ $\operatorname{NMR}\left(300 \mathrm{MHz}, \mathrm{CDCl}_{3}\right) \delta 0.86(\mathrm{~s}, 3 \mathrm{H}), 0.94(\mathrm{~s}, 3 \mathrm{H}), 1.09$ (s, $\left.9 \mathrm{H}\right), 2.99(\mathrm{dd}, J=5.5,6.9 \mathrm{~Hz}, 1 \mathrm{H})$, 3.37 (d, J=2.5 Hz, 1 H), 3.43 (s, $3 \mathrm{H}), 3.44-3.54$ (m, 2 H), 3.92-3.96 (m, $3 \mathrm{H}), 4.06-4.12(\mathrm{~m}, 1 \mathrm{H})$, $4.15(\mathrm{dd}, J=2.2,5.8 \mathrm{~Hz}, 1 \mathrm{H}), 4.52(\mathrm{~d}, J=11.5 \mathrm{~Hz}, 1 \mathrm{H}), 4.65(\mathrm{~d}, J=11.5 \mathrm{~Hz}, 1 \mathrm{H}), 4.81(\mathrm{~d}, J=5.5$ $\mathrm{Hz}, 1 \mathrm{H}), 5.36(\mathrm{~d}, J=5.5 \mathrm{~Hz}, 1 \mathrm{H}), 7.25-7.45(\mathrm{~m}, 11 \mathrm{H}), 7.68-7.74(\mathrm{~m}, 4 \mathrm{H}) ;{ }^{13} \mathrm{C} \mathrm{NMR}(75 \mathrm{MHz}$, $\left.\mathrm{CDCl}_{3}\right) \delta 138.00,135.96,135.78,133.67,133.35,129.86,128.66,128.14,127.87,127.82,90.32$, $86.98,75.67,72.88,72.11,71.63,69.15,63.39,60.86,40.51,26.86,23.95,21.61,19.30$; LRMS $\mathrm{m} / z 521\left(\mathrm{M}^{+}-57\right)$; HRMS calcd for $\mathrm{C}_{30} \mathrm{H}_{37} \mathrm{O}_{6} \mathrm{Si}$ 521.2357, found : 521.2373 ; Anal. Calcd for $\mathrm{C}_{34} \mathrm{H}_{46} \mathrm{O}_{6} \mathrm{Si}: \mathrm{C}, 70.55 ; \mathrm{H}, 8.00$. Found : C, $70.61 ; \mathrm{H}, 8.07$.

To a solution of the alcohol $(0.613 \mathrm{~g}, 1.06 \mathrm{mmol})$ in DMSO $(8 \mathrm{~mL})$ were added $\mathrm{Et}_{3} \mathrm{~N}(1.03 \mathrm{~mL}$, $7.41 \mathrm{mmol})$ and $\mathrm{SO}_{3} \cdot \mathrm{Py}(0.505 \mathrm{~g}, 3.18 \mathrm{mmol})$. The mixture was stirred for $2.5 \mathrm{~h}$, and quenched by $\mathrm{H}_{2} \mathrm{O}$. The resulting mixture was extracted with $\mathrm{Et}_{2} \mathrm{O}$. The combined organic extracts were washed with brine, dried over $\mathrm{MgSO}_{4}$ and concentrated. Purification of the crude product by flash chromatography (17\% EtOAc/hexane) provided an aldehyde $(0.593 \mathrm{~g}, 97 \%)$ as a colorless oil.

Data for the aldehyde : $[\alpha]^{26}{ }_{\mathrm{D}}=+25.40^{\circ}\left(\mathrm{c} 1.10, \mathrm{CHCl}_{3}\right)$; IR (neat) $1722 \mathrm{~cm}^{-1} ;{ }^{1} \mathrm{H}$ NMR (300 $\left.\mathrm{MHz}, \mathrm{CDCl}_{3}\right) \delta 1.04(\mathrm{~s}, 3 \mathrm{H}), 1.08(\mathrm{~s}, 3 \mathrm{H}), 1.09$ (s, $\left.9 \mathrm{H}\right), 3.46(\mathrm{~s}, 3 \mathrm{H}), 3.57$ (d, J= 3.3 Hz, $\left.1 \mathrm{H}\right)$, 3.91-3.93 (m, $3 \mathrm{H}), 4.00(\mathrm{dd}, J=3.3,5.8 \mathrm{~Hz}, 1 \mathrm{H}), 4.06-4.11(\mathrm{~m}, 1 \mathrm{H}), 4.46(\mathrm{~d}, J=11.5 \mathrm{~Hz}, 1 \mathrm{H})$, $4.64(\mathrm{~d}, J=11.5 \mathrm{~Hz}, 1 \mathrm{H}), 4.75(\mathrm{~d}, J=5.5 \mathrm{~Hz}, 1 \mathrm{H}), 5.20(\mathrm{~d}, J=5.8 \mathrm{~Hz}, 1 \mathrm{H}), 7.26-7.43(\mathrm{~m}, 11 \mathrm{H})$, 7.67-7.73 (m, $4 \mathrm{H}) ;{ }^{13} \mathrm{C}$ NMR $\left(75 \mathrm{MHz}, \mathrm{CDCl}_{3}\right) \delta 205.15,138.04,135.92,135.73,133.59,133.24$, $129.83,128.64,128.08,128.02,127.84,127.79,90.04,86.98,75.23,72.76,71.33,63.12,61.20$, 50.38, 26.82, 19.68, 19.35, 19.24, 15.20; LRMS m/z $519\left(\mathrm{M}^{+}-57\right)$; HRMS calcd for $\mathrm{C}_{30} \mathrm{H}_{35} \mathrm{O}_{6} \mathrm{Si}$ 519.2200, found : 519.2189 ; Anal. Calcd for $\mathrm{C}_{34} \mathrm{H}_{44} \mathrm{O}_{6} \mathrm{Si}: \mathrm{C}, 70.79 ; \mathrm{H}, 7.68$. Found : C, $70.90 ; \mathrm{H}$, 7.67 .

To a solution of $\mathrm{Ph}_{3} \mathrm{P}^{+} \mathrm{CH}_{3} \mathrm{Br}^{-}(0.372 \mathrm{~g}, 1.04 \mathrm{mmol})$ in THF $(8 \mathrm{~mL})$ was added BuLi $(0.680 \mathrm{~mL}$, $1.53 \mathrm{M}$ in hexane, $1.04 \mathrm{mmol}$ ) dropwise. The solution was warmed to $65^{\circ} \mathrm{C}$, and stirred for $15 \mathrm{~min}$, then cooled to $0{ }^{\circ} \mathrm{C}$. A solution of the aldehyde $(0.200 \mathrm{~g}, 0.346 \mathrm{mmol})$ in THF $(2 \mathrm{~mL})$ was added at $0{ }^{\circ} \mathrm{C}$ and the mixture was stirred for $20 \mathrm{~min}$. Saturated $\mathrm{NaHCO}_{3}(5 \mathrm{~mL})$ was added to quench the reaction and the resulting mixture was extracted with $\mathrm{Et}_{2} \mathrm{O}$. The combined organic extracts were washed with brine, dried over $\mathrm{MgSO}_{4}$ and concentrated. Purification of the crude product by flash chromatography (9\% EtOAc/hexane) provided olefin $20(0.199 \mathrm{~g}, 100 \%)$ as a white solid.

Data for 20 : mp 86-87 ${ }^{\circ} \mathrm{C}$; $[\alpha]^{22}{ }_{\mathrm{D}}=+9.42^{\circ}\left(\mathrm{c} 0.85, \mathrm{CHCl}_{3}\right)$; IR (neat) $1605 \mathrm{~cm}^{-1} ;{ }^{1} \mathrm{H}$ NMR (300 $\left.\mathrm{MHz}, \mathrm{CDCl}_{3}\right) \delta 1.00(\mathrm{~s}, 3 \mathrm{H}), 1.03(\mathrm{~s}, 3 \mathrm{H}), 1.08$ (s, $\left.9 \mathrm{H}\right), 3.22(\mathrm{~d}, J=4.1 \mathrm{~Hz}, 1 \mathrm{H}), 3.45$ (s, $\left.3 \mathrm{H}\right)$, 3.77 (dd, $J=4.4,6.0 \mathrm{~Hz}, 1 \mathrm{H}), 3.85-3.93(\mathrm{~m}, 2 \mathrm{H}), 3.97$ (t, $J=4.4 \mathrm{~Hz}, 1 \mathrm{H}), 4.15$ ( q, $J=5.8 \mathrm{~Hz}, 1 \mathrm{H})$, $4.47(\mathrm{~d}, J=11.8 \mathrm{~Hz}, 1 \mathrm{H}), 4.66(\mathrm{~d}, J=11.8 \mathrm{~Hz}, 1 \mathrm{H}), 4.75(\mathrm{~d}, J=5.8 \mathrm{~Hz}, 1 \mathrm{H}), 4.92(\mathrm{dd}, J=1.6,10.7$ $\mathrm{Hz}, 1 \mathrm{H}), 4.95$ (dd, $J=1.6,17.6 \mathrm{~Hz}, 1 \mathrm{H}), 5.18$ (d, $J=5.8 \mathrm{~Hz}, 1 \mathrm{H}), 5.88$ ( dd, $J=10.7,17.6 \mathrm{~Hz}, 1 \mathrm{H})$, 7.31-7.43 (m, $11 \mathrm{H}), 7.66-7.71(\mathrm{~m}, 4 \mathrm{H}) ;{ }^{13} \mathrm{C} \mathrm{NMR}\left(75 \mathrm{MHz}, \mathrm{CDCl}_{3}\right) \delta$ 146.1, 138.2, 135.8, 135.7, 133.5, 133.3, 129.9, 128.6, 128.1, 127.9, 127.9, 127.8, 111.7, 90.0, 86.6, 74.7, 73.6, 72.0, 71.9, 
62.8, 61.2, 42.1, 26.8, 25.3, 21.8, 1.92; LRMS m/z $517\left(\mathrm{M}^{+}-57\right)$; HRMS calcd for $\mathrm{C}_{31} \mathrm{H}_{37} \mathrm{O}_{5} \mathrm{Si}$ 517.2408 , found : 517.2410 .

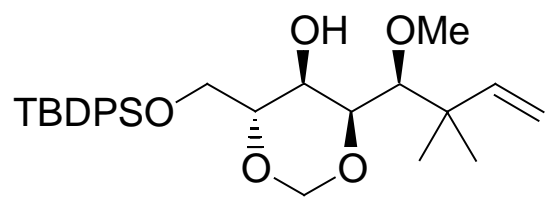

21

\section{(+)-(2R,3R,4R,5S)-1-tert-Butyldiphenylsilyloxy-6,6-dimethyl-3-hydroxy-}

\section{5-methoxy-2,4-methylenedioxyoct-7-en-3-ol (21)}

Liquid $\mathrm{NH}_{3}\left(30 \mathrm{~mL}\right.$ ) was distilled from $\mathrm{Na}$ (solid) via cannula to a $-78{ }^{\circ} \mathrm{C}$ flask, and $\mathrm{Li}$ (solid) $(0.130 \mathrm{~g}, 6.92 \mathrm{mmol})$ was added, immediately producing a blue solution. A solution of benzyl ether $20(0.199 \mathrm{~g}, 0.346 \mathrm{mmol})$ in THF $(9 \mathrm{~mL})$ was added dropwise over $2 \mathrm{~min}$. The mixture was stirred for $20 \mathrm{~min}$, then $\mathrm{NH}_{4} \mathrm{Cl}$ (solid) was added until the blue color disappeared. The solution was allowed to warm to rt and stand for at least $6 \mathrm{~h}$, then quenched by $\mathrm{H}_{2} \mathrm{O}$. The resulting solution was extracted with EtOAc. The combined organic extracts were washed with brine, dried over $\mathrm{MgSO}_{4}$ and concentrated to give a crude oil $(0.176 \mathrm{~g})$.

To a solution of crude product described above $(0.176 \mathrm{~g})$ in benzene $(10 \mathrm{~mL})$ was added DDQ $(0.243 \mathrm{~g}, 1.04 \mathrm{mmol})$. The mixture was stirred for $3.5 \mathrm{~h}$, then saturated $\mathrm{NH}_{4} \mathrm{Cl}$ was added.

The resulting solution was filterd through Celite and the filtrate was extracted with $\mathrm{Et}_{2} \mathrm{O}$. The combined organic extracts were washed with brine, dried over $\mathrm{MgSO}_{4}$ and concentrated to give a crude oil. Purification of the crude product by flash chromatography (13\% EtOAc/hexane) provided alcohol 21 ( $0.124 \mathrm{~g}, 74 \%$ for 2 steps) as a colorless oil.

Data for $21:[\alpha]^{22}{ }_{\mathrm{D}}=+10.28^{\circ}\left(\mathrm{c} 0.50, \mathrm{CHCl}_{3}\right)$; IR (neat) $3400,1605 \mathrm{~cm}^{-1} ;{ }^{1} \mathrm{H} \mathrm{NMR}(300 \mathrm{MHz}$, $\left.\mathrm{CDCl}_{3}\right) \delta 1.05(\mathrm{~s}, 9 \mathrm{H}), 1.06(\mathrm{~s}, 3 \mathrm{H}), 1.09$ (s, $\left.3 \mathrm{H}\right), 3.20(\mathrm{~d}, J=4.9 \mathrm{~Hz}, 1 \mathrm{H}), 3.25(\mathrm{~d}, J=8.2 \mathrm{~Hz}, 1 \mathrm{H})$, 3.53 (s, 3 H), 3.82-3.94 (m, 4 H), 4.00-4.05 (m, 1 H), 4.79 (d, J=6.0 Hz, $1 \mathrm{H}), 4.94$ ( d, J=6.0 Hz, $1 \mathrm{H}), 4.98$ (d, $J=11.3 \mathrm{~Hz}, 1 \mathrm{H}), 4.99$ (d, $J=17.0 \mathrm{~Hz}, 1 \mathrm{H}), 5.97$ ( dd, $J=11.3,17.0 \mathrm{~Hz}, 1 \mathrm{H}$ ), 7.37-7.46 (m, $6 \mathrm{H}), 7.63-7.67$ (m, $4 \mathrm{H}) ;{ }^{13} \mathrm{C} \mathrm{NMR}\left(75 \mathrm{MHz}, \mathrm{CDCl}_{3}\right) \delta 146.0,135.7,133.0,132.8$, 130.2, 128.0, 112.0, 89.8, 87.1, 77.7, 67.1, 62.2, 61.9, 42.1, 26.8, 25.7, 21.4, 19.1; LRMS m/z 427 $\left(\mathrm{M}^{+}-57\right)$; HRMS calcd for $\mathrm{C}_{24} \mathrm{H}_{31} \mathrm{O}_{5} \mathrm{Si} 427.1939$, found : 427.1947.

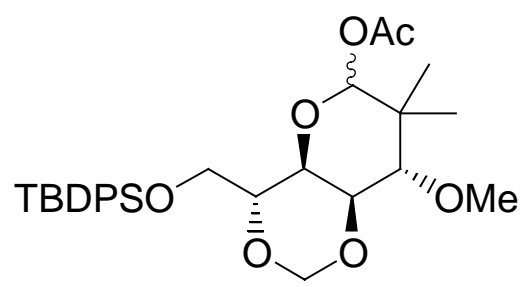


$(1 R, 5 R, 6 R, 8 R S, 10 S)-8$-Acetoxy-5-(tert-butyldiphenylsilyloxy)methyl-9,9-dimethyl10-methoxy-2,4,7-trioxabicyclo[4.4.0]decane (22)

Ozone was bubbled through a $-78{ }^{\circ} \mathrm{C}$ solution of olefin $21(54.0 \mathrm{mg}, 0.111 \mathrm{mmol})$ in $\mathrm{MeOH}(10$ $\mathrm{mL})$ for $15 \mathrm{~min}$. After removal of excess ozone, $\mathrm{Me}_{2} \mathrm{~S}(0.041 \mathrm{~mL}, 0.558 \mathrm{mmol})$ was added and the solution was stirred for $5 \mathrm{~h}$. The solution was concentrated to afford a clear oil (33.5 mg). Due to the instability of the crude lactol, it was immediately used without further purification.

A mixture of crude lactol $(33.5 \mathrm{mg})$ and $\mathrm{Ac}_{2} \mathrm{O}(0.5 \mathrm{~mL})$ in pyridine $(1 \mathrm{~mL})$ was stirred for $16 \mathrm{~h}$. The solvent was removed to leave a crude oil. Purification of the crude product by flash chromatography (14\% EtOAc/hexane) provided acetate diastereomers $22(58.0 \mathrm{mg}, 99 \%$ for 2 steps) in a 1.4:1 ratio, as a colorless oil.

Partial data for 22 : IR (neat) $1745 \mathrm{~cm}^{-1} ;{ }^{1} \mathrm{H}$ NMR $\left(300 \mathrm{MHz}, \mathrm{CDCl}_{3}\right) \delta 0.97(\mathrm{~s}, 1.3 \mathrm{H}), 0.98$ (s, $1.7 \mathrm{H}), 1.07$ (s, $9 \mathrm{H}), 1.17$ (s, 1.7 H), 1.21 (s, 1.3 H), 2.07 (s, $1.3 \mathrm{H}), 2.10$ (s, $1.7 \mathrm{H}), 3.04$ (d, J= 4.4 Hz, 0.4 H), 3.23 (d, J= 3.6 Hz, 0.6 H), 3.42 (s, $1.3 \mathrm{H}), 3.43$ (s, 1.7 H), 3.81-4.21 (m, $5 \mathrm{H}), 4.92$ (d, $J=6.0 \mathrm{~Hz}, 0.4 \mathrm{H}), 4.96(\mathrm{~d}, J=6.0 \mathrm{~Hz}, 0.6 \mathrm{H}), 4.97(\mathrm{~d}, J=5.8 \mathrm{~Hz}, 0.4 \mathrm{H}), 5.08(\mathrm{~d}, J=5.8 \mathrm{~Hz}, 0.6 \mathrm{H})$, 5.71 (s, $0.6 \mathrm{H}), 5.78$ (s, 0.4 H), 7.26-7.47 (m, $6 \mathrm{H})$, 7.65-7.70 (m, $4 \mathrm{H})$; LRMS m/z $471\left(\mathrm{M}^{+}-57\right)$; HRMS calcd for $\mathrm{C}_{25} \mathrm{H}_{31} \mathrm{O}_{7} \mathrm{Si}$ 471.1837, found : 471.1835 ; Anal. Calcd for $\mathrm{C}_{29} \mathrm{H}_{40} \mathrm{O}_{7} \mathrm{Si}: \mathrm{C}, 65.88$; H, 7.62. Found : C, $66.03 ; \mathrm{H}, 7.62$.

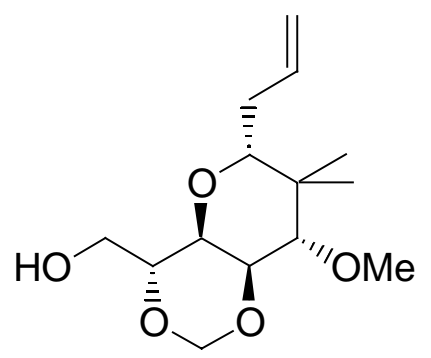

23

(+)-(1R,5R,6R,8R,10S)-5-(Hydroxy)methyl-10-methoxy-9,9-dimethyl -8-(prop-2-enyl)2,4,7-trioxabicyclo[4.4.0]decane (23)

A suspension of acetate $22(10.4 \mathrm{mg}, 0.0197 \mathrm{mmol})$ and activated $4 \AA$ mol. sieves $(0.1 \mathrm{~g})$ in $\mathrm{CH}_{3} \mathrm{CN}(5 \mathrm{~mL})$ was stirred for $30 \mathrm{~min}$ at $0{ }^{\circ} \mathrm{C}$, and allyltrimethylsilane $(0.019 \mathrm{~mL}, 0118 \mathrm{mmol})$ was added. The solution was stirred for $20 \mathrm{~min}$ at $0{ }^{\circ} \mathrm{C}$, and $\mathrm{BF}_{3} \cdot \mathrm{Et}_{2} \mathrm{O}(7.0 \mu \mathrm{L}, 0.059 \mathrm{mmol})$ was added dropwise. The mixture was stirred for an additional $10 \mathrm{~min}$, and quenched by saturated $\mathrm{NaHCO}_{3}(5 \mathrm{~mL})$. After the removal of $4 \AA$ mol. sieves by Celite, the filtrate was extracted with EtOAc $(3 \times 10 \mathrm{~mL})$. The combined organic extracts were washed with brine, dried over $\mathrm{MgSO}_{4}$ and concentrated to give a crude oil. The crude product was purified by flash chromatography. Elution with a 7:1 mixture of hexane-EtOAc afforded a silyl ether $(7.7 \mathrm{mg}, 77 \%)$ as a colorless oil. Elution with a 2:1 mixture of hexane-EtOAc afforded alcohol $23(0.9 \mathrm{mg}, 17 \%)$ as a colorless oil. Data for the silyl ether : $[\alpha]^{26}{ }_{\mathrm{D}}=+75.70^{\circ}$ (c 1.02, $\mathrm{CHCl}_{3}$ ); IR (neat) $1635 \mathrm{~cm}^{-1} ;{ }^{1} \mathrm{H}$ NMR (300 $\left.\mathrm{MHz} \mathrm{CDCl}_{3}\right) \delta 0.87(\mathrm{~s}, 3 \mathrm{H}), 0.94(\mathrm{~s}, 3 \mathrm{H}), 1.30(\mathrm{~s}, 9 \mathrm{H}), 1.95-2.13(\mathrm{~m}, 2 \mathrm{H}), 2.98(\mathrm{dd}, J=2.6,9.5$ 
$\mathrm{Hz}, 1 \mathrm{H}), 3.14(\mathrm{~d}, J=10.2 \mathrm{~Hz}, 1 \mathrm{H}), 3.44(\mathrm{~s}, 3 \mathrm{H}), 3.90$ (ddd, $J=1.6,5.3,10.3 \mathrm{~Hz}, 1 \mathrm{H}), 3.99$ (dd, $J=$ 5.5, $11.3 \mathrm{~Hz}, 1 \mathrm{H}), 4.16$ (dd, J=1.6, $11.3 \mathrm{~Hz}, 1 \mathrm{H}), 4.23$ (dd, J= 6.9, $10.4 \mathrm{~Hz}, 1 \mathrm{H}), 4.35$ (dd, J= 6.9, $10.2 \mathrm{~Hz}, 1 \mathrm{H}), 4.77(\mathrm{~d}, J=6.6 \mathrm{~Hz}, 1 \mathrm{H}), 4.88(\mathrm{~d}, J=6.6 \mathrm{~Hz}, 1 \mathrm{H}), 5.07$ (dt, $J=9.3,0.9 \mathrm{~Hz}, 1 \mathrm{H}), 5.09$ $(\mathrm{dt}, J=17.9,0.9 \mathrm{~Hz}, 1 \mathrm{H}), 5.87$ (ddt, $J=6.6,10.7,17.9 \mathrm{~Hz}, 1 \mathrm{H}), 7.28-7.79$ (m, $6 \mathrm{H}), 7.80-8.03$ (m, $4 \mathrm{H}) ;{ }^{13} \mathrm{C} \mathrm{NMR}\left(75 \mathrm{MHz}, \mathrm{CDCl}_{3}\right) \delta 136.17,135.89,135.86,129.83,129.80,127.82,116.51,87.24$, 79.67, 78.44, 74.05, 73.52, 67.05, 63.80, 61.77, 41.45, 33.39, 26.80, 23.26, 19.30, 13.55; LRMS $m / z, 469\left(\mathrm{M}^{+}-41\right)$; HRMS calcd for $\mathrm{C}_{27} \mathrm{H}_{37} \mathrm{O}_{5} \mathrm{Si} 469.2408$, found : 469.2427 ; Anal. Calcd for $\mathrm{C}_{30} \mathrm{H}_{42} \mathrm{O}_{5} \mathrm{Si}: \mathrm{C}, 70.54 ; \mathrm{H}, 8.28$. Found : C, $70.40 ; \mathrm{H}, 8.05$.

Data for 23; $[\alpha]^{27}{ }_{D}=+79.83^{\circ}\left(\mathrm{c} 1.77, \mathrm{CHCl}_{3}\right)$; IR (neat) $3458,1641,1178,912,841,613 \mathrm{~cm}^{-1}$; ${ }^{1} \mathrm{H}$ NMR $\left(400 \mathrm{MHz}, \mathrm{CDCl}_{3}\right.$ ) $\delta 0.89$ (s, $\left.3 \mathrm{H}\right), 1.01$ (s, $\left.3 \mathrm{H}\right), 2.00-2.08(\mathrm{~m}, 2 \mathrm{H}), 2.18$ (ddd, J=2.0, 6.9, $13.8 \mathrm{~Hz}, 1 \mathrm{H}), 3.28$ (dd, J=2.2, $10.4 \mathrm{~Hz}, 1 \mathrm{H}), 3.44$ (d, J=10.2 Hz, $1 \mathrm{H}), 3.58$ (s, $3 \mathrm{H}), 3.65-3.71(\mathrm{~m}$, $1 \mathrm{H}), 3.82-3.88(\mathrm{~m}, 1 \mathrm{H}), 4.01-4.03(\mathrm{~m}, 2 \mathrm{H}), 4.16(\mathrm{dd}, J=6.4,10.2 \mathrm{~Hz}, 1 \mathrm{H}), 4.86$ (A of AB, J=6.8 $\mathrm{Hz}, 1 \mathrm{H}), 5.02$ (B of AB, $J=6.8 \mathrm{~Hz}, 1 \mathrm{H}), 5.04-5.09$ (m, $2 \mathrm{H}), 5.73-5.83(\mathrm{~m}, 1 \mathrm{H}) ;{ }^{13} \mathrm{C}$ NMR $(75$ $\left.\mathrm{MHz}, \mathrm{CDCl}_{3}\right) \delta 135.9,117.1,86.9,78.5,73.5,72.9,68.4,63.4,61.7,41.6,33.4,23.1,13.1$; LRMS $m / z 272\left(\mathrm{M}^{+}\right)$; Anal. Calcd for $\mathrm{C}_{14} \mathrm{H}_{24} \mathrm{O}_{5}: \mathrm{C}, 61.74 ; \mathrm{H}, 8.88$. Found: C, 61.37 ; H, 8.63.

To a solution of crude products $(64 \mathrm{mg}$, a mixture of the silyl ether and 23 ) in THF $(5 \mathrm{~mL})$ was added TBAF $(0.10 \mathrm{~mL}, 1 \mathrm{M}$ in THF, $0.10 \mathrm{mmol})$. The solution was stirred for $6 \mathrm{~h}$ and saturated $\mathrm{NaHCO}_{3}(1 \mathrm{~mL})$ was added. The resulting mixture was extracted with EtOAc $(3 \mathrm{x} 7 \mathrm{~mL})$. The combined organic extracts were washed with brine, dried over $\mathrm{MgSO}_{4}$ and concentrated to give a crude oil. Purification of the crude product by flash chromatography (33\% EtOAc/hexane) provided alcohol $\mathbf{2 3}$ (25.8 $\mathrm{mg}, 86 \%$ for 2 steps) as a colorless oil.

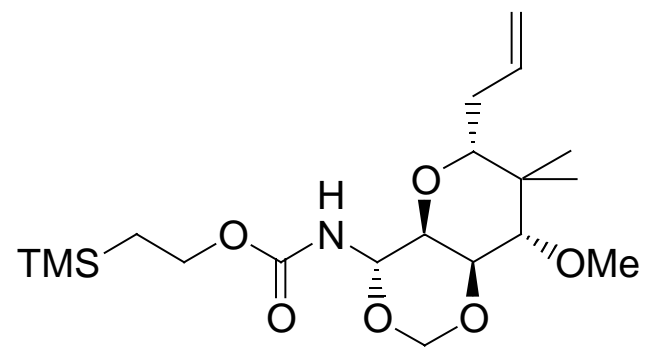

(+)-(1R,5S,6S,8R,10S)-9,9-Dimethyl-10-methoxy-8-(prop-2-enyl)-

\section{5-\{N-[(2-trimethylsilyl)ethoxycarbonyl]amino\}-2,4,7-trioxabicyclo[4.4.0]decane (24)}

To a solution of alcohol $23(5.5 \mathrm{mg}, 0.0202 \mathrm{mmol})$ in acetone $(0.5 \mathrm{~mL})$ was added Jones reagent (approximately $0.06 \mathrm{~mL}$, prepared in according to literature ${ }^{37)}$ ). The mixture was stirred for $0.5 \mathrm{~h}$, and $i-\mathrm{PrOH}(0.2 \mathrm{~mL})$ was added. The solution was concentrated and diluted with $\mathrm{Et}_{2} \mathrm{O}(3 \mathrm{~mL})$. The resulting solution was washed with brine, dried $\left(\mathrm{MgSO}_{4}\right)$ and concentrated to afford a crude carboxylic acid $(7.7 \mathrm{mg})$.

To a suspension of the carboxylic acid $(7.7 \mathrm{mg})$ and activated $4 \AA$ mol. sieves in THF (1.0 mL) were added $\mathrm{Et}_{3} \mathrm{~N}(8.5 \mu \mathrm{L}, 0.0607 \mathrm{mmol})$, DPPA $(4.5 \mu \mathrm{L}, 0.0212 \mathrm{mmol})$ and freshly distilled 
trimethylsilylethanol $(14 \mu \mathrm{L}, 0.101 \mathrm{mmol})$. The mixture was warmed to $65^{\circ} \mathrm{C}$, and stirred for $5.5 \mathrm{~h}$. After filtration, the filtrate was washed with $5 \%$ citric acid aqueous solution, saturated $\mathrm{NaHCO}_{3}$, and brine. The resulting solution was dried $\left(\mathrm{MgSO}_{4}\right)$ and concentrated. Purification of the crude product by flash chromatography (20\% EtOAc/hexanes) provided carbamate $\mathbf{2 4}$ (6.3 $\mathrm{mg}$, $78 \%$ for 2 steps) as a colorless oil.

Data for 24; $[\alpha]^{27}{ }_{D}=+79.83^{\circ}\left(\mathrm{c} 1.77, \mathrm{CHCl}_{3}\right)$; IR (neat) 3323, 1732, 1714, 1531, 1250, 1032, 860 $\mathrm{cm}^{-1} ;{ }^{1} \mathrm{H}$ NMR $\left(300 \mathrm{MHz}, \mathrm{CDCl}_{3}\right) \delta 0.03(\mathrm{~s}, 9 \mathrm{H}), 086(\mathrm{~s}, 3 \mathrm{H}), 0.98(\mathrm{~s}, 3 \mathrm{H}), 0.96-1.01(\mathrm{~m}, 2 \mathrm{H})$, 1.98-2.06 (m, $1 \mathrm{H}), 2.15$ (ddd, J=1.0, 6.0, $14.8 \mathrm{~Hz}, 1 \mathrm{H}), 3.28$ (d, J=9.6 Hz, $1 \mathrm{H}$ ), 3.42 (d, J=10.4 $\mathrm{Hz}, 1 \mathrm{H}), 3.54$ (s, $3 \mathrm{H}), 3.76$ (dd, J=7.2, $10.0 \mathrm{~Hz}, 1 \mathrm{H}), 4.16-4.21(\mathrm{~m}, 3 \mathrm{H}), 4.83$ (d, J=7.2 Hz, $1 \mathrm{H})$, $4.93(\mathrm{~d}, J=10.0 \mathrm{~Hz}, 1 \mathrm{H}), 5.00$ (dd, $J=0.8,17.2 \mathrm{~Hz}, 1 \mathrm{H}), 5.11$ (d, $J=6.8 \mathrm{~Hz}, 1 \mathrm{H}), 5.24$ (br d, $J=8.0$ $\mathrm{Hz}, 1 \mathrm{H}), 5.50$ (br t, $J=9.0 \mathrm{~Hz}, 1 \mathrm{H}), 5.64-5.74(\mathrm{~m}, 1 \mathrm{H}),{ }^{13} \mathrm{C} \mathrm{NMR}\left(75 \mathrm{MHz}, \mathrm{CDCl}_{3}\right) \delta 135.8,116.2$, 86.6, 79.5, 78.5, 76.4, 74.7, 70.7, 63.9, 61.8, 41.6, 33.1, 23.0, 17.6, 13.3, -1.66; LRMS m/z 401 $\left(\mathrm{M}^{+}\right)$; HRMS calcd for $\mathrm{C}_{19} \mathrm{H}_{35} \mathrm{NO}_{6} \mathrm{Si} 401.2234$, found : 401.2245 .

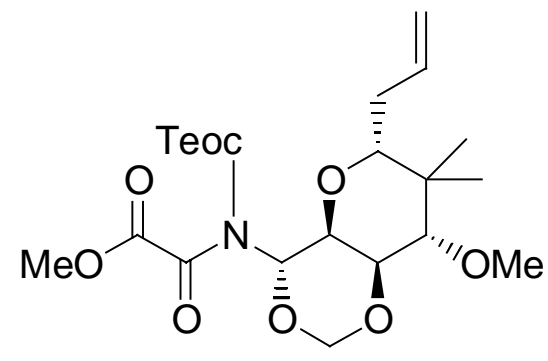

25

\section{(+)-(1S,5R,6S,8R,10S)-10-Methoxy-5-\{N-(methoxalyl)- $N$-[(2-trimethylsilyl)ethoxy-}

\section{carbonyl]amino\}-9,9-dimethyl -8-(prop-2-enyl)-2,4,7-trioxabicyclo[4.4.0]decane (25)}

To a $-78{ }^{\circ} \mathrm{C}$ mixture of carbamate 24 (111.6 mg, $\left.278 \mu \mathrm{mol}\right)$ and DMAP (44.2 $\left.\mathrm{mg}, 362 \mu \mathrm{mol}\right)$ in THF (2.0 mL) was added a solution of LHMDS in THF (0.56 mL, $1.0 \mathrm{M}, 0.56 \mathrm{mmol})$ dropwise over $10 \mathrm{~min}$. The resulting yellow solution was stirred for $0.5 \mathrm{~h}$, at which time a solution of methyl chlorooxoacetate in $\mathrm{CH}_{2} \mathrm{Cl}_{2}(0.14 \mathrm{~mL}, 3.0 \mathrm{M}, 0.42 \mathrm{mmol})$ was added dropwise. The mixture was stirred for $0.5 \mathrm{~h}$ at $-78{ }^{\circ} \mathrm{C}$, and warmed to $0{ }^{\circ} \mathrm{C}$, and stirred for $1 \mathrm{~h}$ at $0{ }^{\circ} \mathrm{C}$, The mixture was allowed to warm to $\mathrm{rt}$, and poured into a slurry of $\mathrm{SiO}_{2}$ in hexane-EtOAc $(2: 1,10 \mathrm{~mL})$. The resulting suspension was vigorously stirred for $15 \mathrm{~min}$, and filtered through Celite. The filtrate was concentrated to give a crude oil. Purification of the crude product by chromatography (25\% EtOAc/hexane) provided imide 25 (105.8 $\mathrm{mg}, 78 \%$; 90\% yield based on the recoverd 24) as a colorless oil, in addition to recovered carbamate $24(14.5 \mathrm{mg}, 13 \%)$.

Data for $25:[\alpha]^{29}{ }_{\mathrm{D}}=+63.74^{\circ}\left(\mathrm{c} 1.80, \mathrm{CHCl}_{3}\right)$; IR (neat) $2955,1714,1715,1541,1252,1177$, $1128,1109,1084,1030,860,839 \mathrm{~cm}^{-1} ;{ }^{1} \mathrm{H} \mathrm{NMR}\left(300 \mathrm{MHz}, \mathrm{CDCl}_{3}\right.$ referenced to $\left.7.24 \mathrm{ppm}\right) \delta$ 0.032 (s, $3 \mathrm{H}), 0.043$ (s, $6 \mathrm{H}), 0.86$ (s, $3 \mathrm{H}), 0.99$ (s, $3 \mathrm{H}), 1.08$ (dd,J=3.6, $6.0 \mathrm{~Hz}, 1 \mathrm{H}), 1.10$ (dd, $J=$ 3.6, $6.0 \mathrm{~Hz}, 1 \mathrm{H}), 1.96-2.07$ (m, $1 \mathrm{H}), 2.10-2.18$ (m, $1 \mathrm{H}), 3.26$ (dd, J=2.0, $10.0 \mathrm{~Hz}, 1 \mathrm{H}), 3.44$ (d, $J=10.4 \mathrm{~Hz}, 1 \mathrm{H}), 3.56$ (s, $3 \mathrm{H}), 3.87$ (s, $3 \mathrm{H}), 4.30$ (dd, $J=7.2,10.8 \mathrm{~Hz}, 1 \mathrm{H}), 4.32$ ( dd, J= 3.6, 6.0 
$\mathrm{Hz}, 1 \mathrm{H}), 4.34(\mathrm{dd}, J=3.2,6.0 \mathrm{~Hz}, 1 \mathrm{H}), 4.84(\mathrm{dd}, J=7.2,10.2 \mathrm{~Hz}, 1 \mathrm{H}), 4.90-5.03(\mathrm{~m}, 2 \mathrm{H}), 4.95$ (d, $J=6.8 \mathrm{~Hz}, 1 \mathrm{H}), 5.09$ (d, $J=6.8 \mathrm{~Hz}, 1 \mathrm{H}), 5.66$ (tdd, $J=6.8,10.0,16.8 \mathrm{~Hz}, 1 \mathrm{H}), 6.10(\mathrm{~d}, J=10.4 \mathrm{~Hz}$, $1 \mathrm{H}) ;{ }^{13} \mathrm{C} \mathrm{NMR}\left(100 \mathrm{MHz}, \mathrm{CDCl}_{3}\right) \delta 162.62,160.96,152.22,135.59,116.33,87.60,79.43,78.77$, 77.32, 75.05, 67.51, 61.84, 52.91, 41.66, 33.58, 23.06, 17.42, 13.27, -1.41, -1.54, -1.54; LRMS $m / z 446\left(\mathrm{M}^{+}-41, \mathrm{CH}_{2} \mathrm{CH}=\mathrm{CH}_{2}\right)$; HRMS calcd for $\mathrm{C}_{19} \mathrm{H}_{32} \mathrm{O}_{9} \mathrm{NSi} 446.1847$, found : 446.1835 .

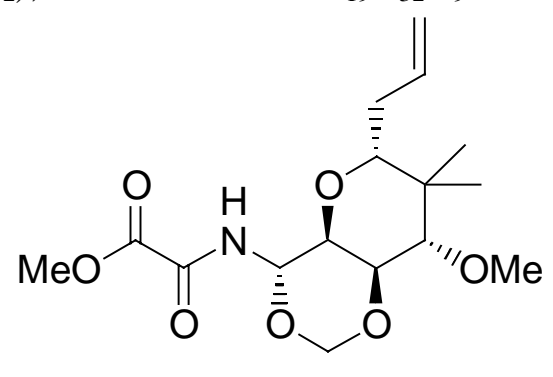

2

\section{(+)-(1S,5R,6S,8R,10S)-10-Methoxy-5-\{N-(methoxalyl)amino\}-9,9-dimethyl-}

\section{8-(prop-2-enyl)-2,4,7-trioxabicyclo[4.4.0]decane (2)}

To a $0{ }^{\circ} \mathrm{C}$ solution of imide 25 ( $\left.98.3 \mathrm{mg}, 0.202 \mathrm{mmol}\right)$ in THF $(3.0 \mathrm{~mL})$ was added TBAF $(0.30$ $\mathrm{mL}, 1.0 \mathrm{M}, 0.30 \mathrm{mmol})$. After $5 \mathrm{~min}$, a mixture of $\mathrm{CH}_{2} \mathrm{Cl}_{2}(10 \mathrm{~mL})$ and $\mathrm{H}_{2} \mathrm{O}(10 \mathrm{~mL})$ was added. The aqueous phase was separated and further extracted with $\mathrm{CH}_{2} \mathrm{Cl}_{2}(2 \times 10 \mathrm{~mL})$. The combined organic extracts were dried $\left(\mathrm{Na}_{2} \mathrm{SO}_{4}\right)$ and concentrated to afford a crude yellow solid. Purification of the crude product by flash chromatography (50\% EtOAc/hexane) provided methyl oxalate 2 $(64.5 \mathrm{mg}, 93 \%)$ as a white solid, in addition to carbamate $\mathbf{2 4}(3.3 \mathrm{mg}, 4.1 \%)$. The methyl oxalate 2 was used immediately in the next step.

Data for 2 : $\mathrm{mp} 168-170{ }^{\circ} \mathrm{C}$; IR (KBr) 3315, 1738, 1701, 1541, 1263, 1182, 1123, 1103, 1076, 1036, 978, $907 \mathrm{~cm}^{-1} ;{ }^{1} \mathrm{H} \mathrm{NMR}\left(400 \mathrm{MHz}, \mathrm{CDCl}_{3}\right.$ referenced to $\left.7.24 \mathrm{ppm}\right) \delta 0.88(\mathrm{~s}, 3 \mathrm{H}), 1.02(\mathrm{~s}, 3 \mathrm{H})$, 1.97-2.05 (m, $1 \mathrm{H}), 2.16$ (dddd, $J=1.6,2.0,6.0,14.4 \mathrm{~Hz}, 1 \mathrm{H}), 3.29$ (dd, $J=2.0,10.0 \mathrm{~Hz}, 1 \mathrm{H}), 3.46$ (d, J=10.8 Hz, 1 H), 3.57 (s, 3 H), 3.91 (dd, J=6.8, 10.0 Hz, 1 H), 3.93 (s, 3 H), 4.25 (dd, J=6.4, $10.4 \mathrm{~Hz}, 1 \mathrm{H}$ ), 4.88 (d, J=6.8 Hz, $1 \mathrm{H}$ ), 4.88 ( br d, $J=6.8 \mathrm{~Hz}, 1 \mathrm{H}$ ), 4.97 (dddd, $J=1.4,1.4,3.2$, $17.2 \mathrm{~Hz}, 1 \mathrm{H}), 5.15$ (d, $J=7.2 \mathrm{~Hz}, 1 \mathrm{H}), 5.63$ (tdd, $J=6.8,10.4,17.2 \mathrm{~Hz}, 1 \mathrm{H}), 5.74$ (dd, $J=10.0$, $10.0 \mathrm{~Hz}, 1 \mathrm{H}), 7.55(\mathrm{~d}, J=9.2 \mathrm{~Hz}, 1 \mathrm{H}) ;{ }^{13} \mathrm{C} \mathrm{NMR}\left(100 \mathrm{MHz}, \mathrm{CDCl}_{3}\right) \delta 159.98,156.23,135.45$, 116.22, 86.69, 79.34, 78.67, 74.63, 74.11, 70.37, 61.78, 53.85, 41.71, 33.25, 23.11, 13.43; LRMS $m / z 344\left(\mathrm{M}^{+}+\mathrm{H}\right)$; HRMS calcd for $\mathrm{C}_{16} \mathrm{H}_{26} \mathrm{O}_{7} \mathrm{~N} 344.1709$, found : 344.1711 .

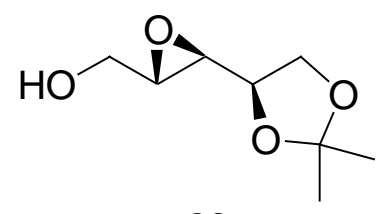

33

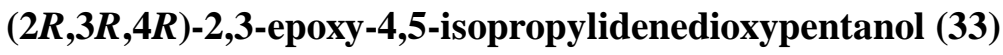

To a $-78{ }^{\circ} \mathrm{C}$ solution of ethyl (S)-4,5-isoprorylidenedioxy-2-pentenoate $(\mathbf{3 2})^{2)}(0.980 \mathrm{~g}, 4.91 \mathrm{mmol})$ 
in THF $(20 \mathrm{~mL})$ was added DIBAL-H in hexanes $(10.3 \mathrm{~mL}, 1.0 \mathrm{M}, 10.3 \mathrm{mmol})$. The mixture was stirred for $3.5 \mathrm{~h}$ at $-78{ }^{\circ} \mathrm{C}$, then $\mathrm{H}_{2} \mathrm{O}(10 \mathrm{~mL})$ was added. The solution was stirred for $30 \mathrm{~min}$ at -78 ${ }^{\circ} \mathrm{C}$, at which time $\mathrm{Et}_{2} \mathrm{O}(10 \mathrm{~mL})$ and hexane $(10 \mathrm{~mL})$ were added. The solution was allowed to warm to rt, then filtered through Celite. The resulting clear solution was concentrated to afford a crude oil. Purification of the crude product by flash chromatography (50\% EtOAc/hexane) provided $(S)$-4,5-isopropylidenedioxy-2-pentenol (0.682 g, 88\%), in addition to recovered ester 32 $(0.110 \mathrm{~g}, 11 \%)$. To a $-40{ }^{\circ} \mathrm{C}$ suspension of $\mathrm{Ti}\left(\mathrm{O}^{i} \mathrm{Pr}\right)_{4}(0.110 \mathrm{~mL}, 0.374 \mathrm{mmol})$ and powdered activated $3 \AA$ mol. sieves $(0.2 \mathrm{~g})$ in $\mathrm{CH}_{2} \mathrm{Cl}_{2}(5 \mathrm{~mL})$ was added a solution of (+)-DIPT $(0.087 \mathrm{~mL}$, $0.416 \mathrm{mmol})$ in $\mathrm{CH}_{2} \mathrm{Cl}_{2}(2 \mathrm{~mL})$. The mixture was stirred for $40 \mathrm{~min}$ at $-40{ }^{\circ} \mathrm{C}$, then the solution of (S)-4,5-isopropylidenedioxy- 2-pentenol (0.658 g, $4.16 \mathrm{mmol})$ in $\mathrm{CH}_{2} \mathrm{Cl}_{2}(2 \mathrm{~mL})$ was added. After $1.5 \mathrm{~h}$, cumene hydroperoxide $(1.84 \mathrm{~mL}, 12.5 \mathrm{mmol})$ was added dropwise over $3 \mathrm{~min}$. The resulting solution was stirred for $89 \mathrm{~h}$ at $-40{ }^{\circ} \mathrm{C}$, then cooled to $-78{ }^{\circ} \mathrm{C}$ and stirred for $10 \mathrm{~min}$. $\mathrm{Bu}_{3} \mathrm{P}(2.09 \mathrm{~mL}$, $8.05 \mathrm{mmol}$ ) was added dropwise over $10 \mathrm{~min}$ to quench the reaction. The mixture was stirred for $30 \mathrm{~min}$, then treated with citric acid monohydrate (ca. $87 \mathrm{mg}, 0.42 \mathrm{mmol}$ ) dissolved in acetone-ether $(1: 9,6 \mathrm{~mL})$. The cooling bath was removed, and the resulting mixture was stirred for an additional $40 \mathrm{~min}$. After filtration through a pad of Celite, the filtrate was dried over $\mathrm{MgSO}_{4}$ and concentrated to give an oil. Purification of the oil by flash chromatography (33\% EtOAc/hexanes) provided epoxide $33(0.644 \mathrm{~g}, 89 \%)$. The identity of epoxide 33 was confirmed by comparison with reported spectral data ${ }^{3)}{ }^{4)} ;[\alpha]^{23}{ }_{\mathrm{D}}=-21.36^{\circ}\left(\mathrm{c} 1.80, \mathrm{CHCl}_{3}\right)$, literature ${ }^{5}[\alpha]_{\mathrm{D}}=-21.5^{\circ}(\mathrm{c} 0.77$, $\mathrm{CHCl}_{3}$ ); IR (neat) $3435,1637,1376,1217,1058 \mathrm{~cm}^{-1} ;{ }^{1} \mathrm{H} \mathrm{NMR}\left(500 \mathrm{MHz}, \mathrm{CDCl}_{3}\right.$ referenced to $7.26 \mathrm{ppm}) \delta 1.37$ (s, $3 \mathrm{H}), 1.43$ (s, $3 \mathrm{H}), 1.89(\mathrm{dd}, J=5.5,7.3 \mathrm{~Hz}, 1 \mathrm{H}), 3.11(\mathrm{dd}, J=2.3,4.6 \mathrm{~Hz}, 1 \mathrm{H})$, $3.15(\mathrm{td}, J=2.3,3.7 \mathrm{~Hz}, 1 \mathrm{H}), 3.68$ (ddd, $J=3.7,7.4,12.4 \mathrm{~Hz}, 1 \mathrm{H}), 3.83-3.88$ (m, $1 \mathrm{H}), 3.95$ (ddd, $J=2.3,5.0,12.8 \mathrm{~Hz}, 1 \mathrm{H}), 4.09(\mathrm{dt}, J=5.1,6.9 \mathrm{~Hz}, 1 \mathrm{H}), 4.11(\mathrm{dd}, J=6.4,13.8 \mathrm{~Hz}, 1 \mathrm{H}) ;{ }^{13} \mathrm{C} \mathrm{NMR}$ $\left(100 \mathrm{MHz}, \mathrm{CDCl}_{3}\right) \delta 110.01,75.13,65.95,60.79,55.37,54.99,26.28,25.47$.

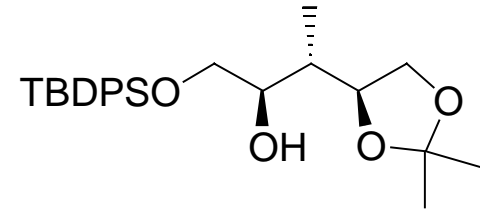

34

(1,2-diol)

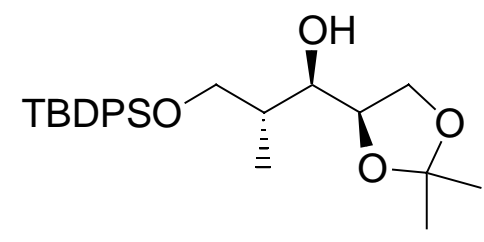

(1,3-diol)

$(2 S, 3 S, 4 R)$-1-tert-Butyldiphenylsilyloxy-4,5-isopropylidenedioxy-

3-methylpentan-2-ol (34, 1,2-diol)

$(2 R, 3 R, 4 R)$-1-tert-Butyldiphenylsilyloxy-4,5-isopropylidenedioxy-

2-methylpentan-3-ol (1,3-diol) 
To a $0{ }^{\circ} \mathrm{C}$ solution of epoxide $33(29.8 \mathrm{mg}, 0.171 \mathrm{mmol})$ and $\mathrm{Et}_{3} \mathrm{~N}(0.119 \mathrm{~mL}, 0.856 \mathrm{mmol})$ in $\mathrm{CH}_{2} \mathrm{Cl}_{2}(5 \mathrm{~mL})$ were added TBDPSCl $(89.0 \mu \mathrm{L}, 0.342 \mathrm{mmol})$ and DMAP $(5.0 \mathrm{mg}, 0.0409 \mathrm{mmol})$. The mixture was stirred for $10 \mathrm{~h}$ at $\mathrm{rt}$, then cooled to $0{ }^{\circ} \mathrm{C}$, and quenched by $\mathrm{H}_{2} \mathrm{O}(10 \mathrm{~mL})$. The phases were separated and the aqueous phase was further extracted with $\mathrm{Et}_{2} \mathrm{O}(3 \times 30 \mathrm{~mL})$. The combined organic extracts were washed with brine $(30 \mathrm{~mL})$, dried $\left(\mathrm{MgSO}_{4}\right)$, and concentrated. Purification of the crude product by flash chromatography (9\% EtOAc/hexane) provided a silyl ether $\left(173 \mathrm{mg}\right.$, including any remaining silanol). To a $-20{ }^{\circ} \mathrm{C}$ suspension of $\mathrm{CuI}(0.456 \mathrm{~g}, 2.40$ $\mathrm{mmol})$ in $\mathrm{Et}_{2} \mathrm{O}(5 \mathrm{~mL})$ was added $\mathrm{MeLi}\left(5.26 \mathrm{~mL}, 1.14 \mathrm{M}_{\text {in }} \mathrm{Et}_{2} \mathrm{O}, 5.99 \mathrm{mmol}\right)$ dropwise over 5 min. When the yellow color had disappeared, the solution was cooled to $-40{ }^{\circ} \mathrm{C}$, then the silyl ether described above in $\mathrm{Et}_{2} \mathrm{O}(2 \mathrm{~mL})$ was added. The mixture was stirred for $1 \mathrm{~h}$ between $-40{ }^{\circ} \mathrm{C}$ and $-30{ }^{\circ} \mathrm{C}$, quenching with a mixture of concd. $\mathrm{NH}_{4} \mathrm{OH}$ and saturated $\mathrm{NH}_{4} \mathrm{Cl}(1: 9,10 \mathrm{~mL})$. The resulting mixture was allowed to warm to rt, and stirred for $20 \mathrm{~min}$, then filtered through Celite. The phases were separated and the aqueous phase was further extracted with $\mathrm{Et}_{2} \mathrm{O}(3 \times 15 \mathrm{~mL})$. The combined organic extracts were washed with brine $(10 \mathrm{~mL})$, dried $\left(\mathrm{MgSO}_{4}\right)$, and concentrated. Purification of the crude product by flash chromatography (9\% EtOAc/hexane) provided a mixture of 34 and 1,3-diol $(64.6 \mathrm{mg}, 0.151 \mathrm{mmol}, 88 \%$ from 33$)$ in a 7:1 ratio.

Partial data for 34 and 1,3-diol: ${ }^{1} \mathrm{H}$ NMR $\left(400 \mathrm{MHz}, \mathrm{CDCl}_{3}\right) \delta 0.81(\mathrm{~d}, J=6.8 \mathrm{~Hz}, 2.6 \mathrm{H}), 1.00(\mathrm{~d}$, $J=6.8 \mathrm{~Hz}, 0.4 \mathrm{H}), 1.06(\mathrm{~s}, 1.1 \mathrm{H}), 1.07$ (s, $7.9 \mathrm{H}), 1.33(\mathrm{~s}, 2.6 \mathrm{H}), 1.36$ (s, $0.4 \mathrm{H}), 1.38$ (s, $2.6 \mathrm{H})$, $1.44(\mathrm{~s}, 0.4 \mathrm{H}), 1.78-1.88(\mathrm{~m}, 0.1 \mathrm{H}), 1.96(\mathrm{dq}, J=13.6,6.8 \mathrm{~Hz}, 0.9 \mathrm{H}), 2.83(\mathrm{~d}, J=6.4 \mathrm{~Hz}, 0.1 \mathrm{H})$, $3.12(\mathrm{~d}, J=2.8 \mathrm{~Hz}, 0.9 \mathrm{H}), 3.45-3.50(\mathrm{~m}, 0.3 \mathrm{H}), 3.56-3.59(\mathrm{~m}, 0.3 \mathrm{H}), 3.56-3.59(\mathrm{~m}, 0.1 \mathrm{H})$, 3.61-3.67 (m, 1.8 H), 3.70 (dd, $J=10.4,4.0 \mathrm{~Hz}, 0.9 \mathrm{H}), 3.75$ (dd, $J=10.0,3.2 \mathrm{~Hz}, 0.9 \mathrm{H}), 3.78$ (dd, $J=10.4,4.4 \mathrm{~Hz}, 0.1 \mathrm{H}), 3.85$ (t, $J=7.6 \mathrm{~Hz}, 0.1 \mathrm{H}), 3.99$ (dd, $J=10.0,6.4 \mathrm{~Hz}, 0.1 \mathrm{H}), 4.02$ (dd, $J=8.0$, $6.0 \mathrm{~Hz}, 0.9 \mathrm{H}), 4.12$ (dt, J= 6.4, 7.6 Hz, 0.9 H), 4.22-4.27 (m, 0.1 H), 7.36-7.44 (m, $6 \mathrm{H}), 7.67$ (dd, $J=3.2,1.6 \mathrm{~Hz}, 2 \mathrm{H}), 7.69$ (dd, $J=2.8,1.2 \mathrm{~Hz}, 2 \mathrm{H})$.

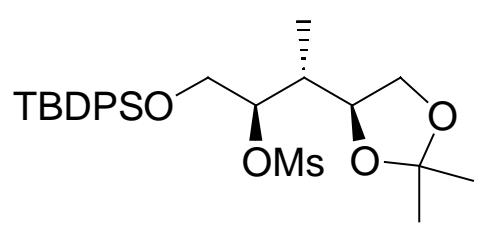

35

\section{(-)-(2S,3R,4R)-1-tert-Butyldiphenylsilyloxy-4,5-isopropylidenedioxy-2-mesyloxy-}

\section{3-methylpentane (35)}

To a $0{ }^{\circ} \mathrm{C}$ solution of alcohols $(0.205 \mathrm{~g}, 0.479 \mathrm{mmol}$; a $7: 1$ mixture of $\mathbf{3 4}$ and 1,3-diol $)$ in $\mathrm{CH}_{2} \mathrm{Cl}_{2}$ $(5 \mathrm{~mL})$ were added $\mathrm{Et}_{3} \mathrm{~N}(0.33 \mathrm{~mL}, 2.40 \mathrm{mmol})$ and $\mathrm{MsCl}(0.048 \mathrm{~mL}, 0.623 \mathrm{mmol})$. The mixture was stirred for $30 \mathrm{~min}$, then poured into saturated $\mathrm{NaHCO}_{3}(10 \mathrm{~mL})$. The phases were separated 
and the aqueous phase was further extracted with $\mathrm{Et}_{2} \mathrm{O}(3 \times 15 \mathrm{~mL})$. The combined organic extracts were washed with brine $(10 \mathrm{~mL})$, dried $\left(\mathrm{MgSO}_{4}\right)$, and concentrated to give a yellow oil. The crude oil was chromatographed ( $11 \%$ EtOAc/hexane) to remove any remaining $\mathrm{Et}_{3} \mathrm{~N}$, then recrystallized twice from $\mathrm{Et}_{2} \mathrm{O}$ to yield methanesulfonate $35(0.168 \mathrm{~g}, 69 \%)$ as colorless prisms.

Data for 35: $\mathrm{mp} 113{ }^{\circ} \mathrm{C}$; $[\alpha]^{23}{ }_{\mathrm{D}}=-10.45^{\circ}\left(\mathrm{c} 0.60, \mathrm{CHCl}_{3}\right)$; IR $(\mathrm{KBr}) 1360,1176,1113,915,703$ $\mathrm{cm}^{-1} ;{ }^{1} \mathrm{H}$ NMR $\left(300 \mathrm{MHz}, \mathrm{CDCl}_{3}\right) \delta 0.90(\mathrm{~d}, J=7.2 \mathrm{~Hz}, 3 \mathrm{H}), 1.06(\mathrm{~s}, 9 \mathrm{H}), 1.30$ (s, $\left.3 \mathrm{H}\right), 1.36$ (s, 3 H), 2.18 (ddq, $J=10.9,6.8,3.8 \mathrm{~Hz}, 1 \mathrm{H}), 3.04$ (s, $3 \mathrm{H}), 3.59$ (dd, $J=6.3,7.4 \mathrm{~Hz}, 1 \mathrm{H}), 3.85$ (dd, $J=$ 3.2, $11.7 \mathrm{~Hz}, 1 \mathrm{H}), 3.89-4.02(\mathrm{~m}, 3 \mathrm{H}), 4.93(\mathrm{~m}, 1 \mathrm{H}), 7.40-7.48(\mathrm{~m}, 6 \mathrm{H}), 7.66-7.70(\mathrm{~m}, 4 \mathrm{H}) ;{ }^{13} \mathrm{C}$ NMR $\left(75 \mathrm{MHz}, \mathrm{CDCl}_{3}\right) \delta 135.6,135.5,132.9,132.7,130.0,127.9,109.1,85.7,76.2,67.8,63.7$, 39.5, 38.4, 26.7, 26.4, 19.0, 11.1 ; LRMS m/z $491\left(\mathrm{M}^{+}-15\right)$; Anal. Calcd for $\mathrm{C}_{26} \mathrm{H}_{38} \mathrm{O}_{6} \mathrm{SSi}$ : C, $61.63 ; \mathrm{H}, 7.56$; S, 6.33. Found : C, 61.53 ; H, 7.67 ; S, 6.41.

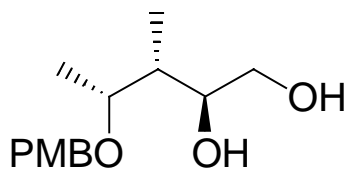

36

\section{(-)-(2R,3R,4R)-4-(4-Methoxybenzyl)oxy-3-methylpentan-1,2-diol (36)}

To a solution of methanesulfonate $35(1.23 \mathrm{~g}, 2.42 \mathrm{mmol})$ in THF $(10 \mathrm{~mL})$ was added TBAF (3.6 $\mathrm{mL}, 1.0 \mathrm{M}$ in THF, $3.6 \mathrm{mmol})$. The mixture was stirred for $50 \mathrm{~min}$, then saturated $\mathrm{K}_{2} \mathrm{CO}_{3}(10 \mathrm{~mL})$ was added. The mixture was stirred for an additional $10 \mathrm{~min}$. The phases were separated and the aqueous phase was further extracted with $\mathrm{Et}_{2} \mathrm{O}(3 \mathrm{x} 20 \mathrm{~mL})$. The combined organic extracts were washed with brine, dried $\left(\mathrm{MgSO}_{4}\right)$, and concentrated, providing the intermediate (crude) epoxide $(0.46 \mathrm{~g})$ which was used immediately in the next step.

To a $23{ }^{\circ} \mathrm{C}$ bath cooled suspension of $\mathrm{LiAlH}_{4}(0.184 \mathrm{~g}, 4.85 \mathrm{mmol})$ in $\mathrm{Et}_{2} \mathrm{O}(10 \mathrm{~mL})$ was added a solution of the crude epoxide in $\mathrm{Et}_{2} \mathrm{O}(2 \mathrm{~mL})$ dropwise. The mixture was stirred for $12 \mathrm{~h}$ at $\mathrm{rt}$, then cooled to $0{ }^{\circ} \mathrm{C}$, and $\mathrm{H}_{2} \mathrm{O}(0.18 \mathrm{~mL})$ was added. After $15 \mathrm{~min}, 15 \% \mathrm{NaOH}(0.18 \mathrm{~mL})$ and $\mathrm{H}_{2} \mathrm{O}(0.55$ $\mathrm{mL})$ were added and the resulting solution was stirred for an additional $2 \mathrm{~h}$ at $\mathrm{rt} . \mathrm{MgSO}_{4}(0.5 \mathrm{~g})$ was added, and the solution was filterd through Celite and concentrated to afford a crude alcohol $(0.42 \mathrm{~g})$. This crude alcohol was immediately used without further purification.

To a $0{ }^{\circ} \mathrm{C}$ suspension of $\mathrm{NaH}(0.485 \mathrm{~g}, 12.1 \mathrm{mmol})$ in $\mathrm{DMF}(5 \mathrm{~mL})$ was added the solution of the crude alcohol $(0.42 \mathrm{~g})$ in DMF $(2 \mathrm{~mL})$. The mixture was stirred for $1 \mathrm{~h}$ at $0{ }^{\circ} \mathrm{C}$, and warmed to $\mathrm{rt}$, then $\mathrm{MPMCl}(0.43 \mathrm{~mL}, 3.15 \mathrm{mmol})$ was added. The solution was stirred for $7 \mathrm{~h}$ at $\mathrm{rt}$, then cooled to $0{ }^{\circ} \mathrm{C} . \mathrm{H}_{2} \mathrm{O}(5 \mathrm{~mL})$ was added slowly to quench the reaction. The resulting solution was extracted with $\mathrm{Et}_{2} \mathrm{O}(3 \mathrm{x} 15 \mathrm{~mL})$. The combined organic extracts were washed with brine $(15 \mathrm{~mL})$, dried $\left(\mathrm{MgSO}_{4}\right)$ and concentrated to afford a crude $p$-methoxybenzyl ether $(1.0 \mathrm{~g})$ which was dissolved in AcOH-THF- $\mathrm{H}_{2} \mathrm{O}(3: 1: 1,5 \mathrm{~mL})$. The mixture was warmed to $55^{\circ} \mathrm{C}$, and stirred for $9 \mathrm{~h}$. After the removal of the solvents by azeotropic distillation, the residue was purified by flash chromatography (50\% EtOAc/hexane) to provide diol $36(0.482 \mathrm{~g}, 78 \%$ from 35) as a colorless oil. 
Data for 36: $[\alpha]^{24}=-10.00^{\circ}$ (c 1.09, $\mathrm{CHCl}_{3}$ ); IR (neat) $3414,1613,1512,1246,1038,822,421$ $\mathrm{cm}^{-1} ;{ }^{1} \mathrm{H}$ NMR $\left(300 \mathrm{MHz}, \mathrm{CDCl}_{3}\right) \delta 0.85(\mathrm{~d}, J=7.2 \mathrm{~Hz}, 3 \mathrm{H}), 1.23(\mathrm{~d}, J=6.3 \mathrm{~Hz}, 3 \mathrm{H}), 1.98-2.10$ (m, $1 \mathrm{H}), 2.25(\mathrm{br} \mathrm{s}, 1 \mathrm{H}), 3.51(\mathrm{dd}, J=5.7,11.4 \mathrm{~Hz}, 1 \mathrm{H}), 3.66-3.79(\mathrm{~m}, 3 \mathrm{H}), 3.81(\mathrm{~s}, 3 \mathrm{H}), 4.16$ (br $\mathrm{s}, 1 \mathrm{H}), 4.44(\mathrm{~d}, J=10.8 \mathrm{~Hz}, 1 \mathrm{H}), 4.55(\mathrm{~d}, J=10.8 \mathrm{~Hz}, 1 \mathrm{H}), 6.88(\mathrm{~d}, J=8.7 \mathrm{~Hz}, 2 \mathrm{H}), 7.25$ (d, $J=8.7$ $\mathrm{Hz}, 2 \mathrm{H}) ;{ }^{13} \mathrm{C}$ NMR $\left(75 \mathrm{MHz}, \mathrm{CDCl}_{3}\right) \delta 159.4,130.1,129.3,113.9,77.6,70.2,64.8,55.1,37.8$, 14.4, 12.2; LRMS m/z $254\left(\mathrm{M}^{+}\right)$; HRMS calcd for $\mathrm{C}_{14} \mathrm{H}_{22} \mathrm{O}_{4} 254.1518$, found : 254.1504 .

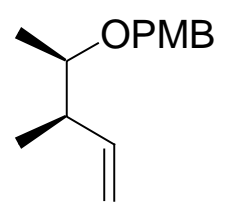

37

\section{(+)-(3R,4R)-4-(4-Methoxybenzyl)oxy-3-methylpentene (37)}

To a mixture of diol $36(1.46 \mathrm{~g}, 5.75 \mathrm{mmol})$ and $\mathrm{K}_{2} \mathrm{CO}_{3}(3.18 \mathrm{~g}, 23.0 \mathrm{mmol})$ in benzene $(50 \mathrm{~mL})$ was added $\mathrm{Pb}(\mathrm{OAc})_{4}(5.61 \mathrm{~g}, 12.6 \mathrm{mmol})$. The mixture was stirred for $1.5 \mathrm{~h}$ and then filtered through Celite. The filtrate was concentrated to give a colorless oil which was used immediately in the next step.

To a $0{ }^{\circ} \mathrm{C}$ suspension of $\mathrm{MePPh}_{3}{ }^{+} \mathrm{Br}^{-}(3.08 \mathrm{~g}, 8.62 \mathrm{mmol})$ in THF $(20 \mathrm{~mL})$ was added BuLi (6.48 $\mathrm{mL}, 1.33 \mathrm{M}$ in hexane, $8.62 \mathrm{mmol}$ ) dropwise over $5 \mathrm{~min}$. The resulting yellow solution was warmed to $\mathrm{rt}$ and stirred for $20 \mathrm{~min}$. After the yellow solids had dissipated, a solution of crude aldehyde in THF $(10 \mathrm{~mL})$ was added at $0{ }^{\circ} \mathrm{C}$. The solution was allowed to warm to rt and stirred for $2 \mathrm{~h}$. Saturated $\mathrm{NH}_{4} \mathrm{Cl}(15 \mathrm{~mL})$ was added to quench the reaction. The phases were separated and the aqueous phase was further extracted with EtOAc $(3 \times 50 \mathrm{~mL})$. The combined organic extracts were washed with brine, dried $\left(\mathrm{MgSO}_{4}\right)$ and concentrated to give a crude oil. Purification of the crude oil by flash chromatography (5\% EtOAc/hexane) provided alkene $37(0.834 \mathrm{~g}, 69 \%$ for 2 steps) as a colorless oil.

Data for 37: $[\alpha]^{29}{ }_{\mathrm{D}}=+2.20^{\circ}$ (c 1.16, $\mathrm{CHCl}_{3}$ ); IR (neat) $1614,1514,1456,1248,1092,1038,822$ $\mathrm{cm}^{-1} ;{ }^{1} \mathrm{H}$ NMR (400 MHz, $\mathrm{CDCl}_{3}$ referenced to $\left.7.24 \mathrm{ppm}\right) \delta 7.26(\mathrm{td}, J=2.5,8.4 \mathrm{~Hz}, 2 \mathrm{H}), 6.86(\mathrm{td}$, $J=2.8,8.4 \mathrm{~Hz}, 2 \mathrm{H}), 5.81$ (ddd, $J=7.6,10.8,18.0 \mathrm{~Hz}, 1 \mathrm{H}$ ), 5.04 (ddd, $J=1.6,2.0,17.6 \mathrm{~Hz}, 1 \mathrm{H}$ ), 5.01 (ddd, $J=1.2,2.0,10.0 \mathrm{~Hz}, 1 \mathrm{H}), 4.51$ (d, $J=11.2 \mathrm{~Hz}, 1 \mathrm{H}), 4.41$ (d, $J=11.2 \mathrm{~Hz}, 1 \mathrm{H}), 3.80$ (s, 3 H), 3.34 (qd, $J=6.4,12.4 \mathrm{~Hz}, 1 \mathrm{H}), 2.36$ (ddq, $J=6.8,6.8,6.8 \mathrm{~Hz}, 1 \mathrm{H}), 1.12$ (d, $J=6.0 \mathrm{~Hz}, 3 \mathrm{H}), 1.03$ $(\mathrm{d}, J=6.8 \mathrm{~Hz}, 3 \mathrm{H}) ;{ }^{13} \mathrm{C}$ NMR $\left(100 \mathrm{MHz}, \mathrm{CDCl}_{3}\right) \delta 158.86,140.74,131.04,128.98,114.31,113.96$, 78.07, 70.27, 55.21, 43.04, 16.69; LRMS m/z $220\left(\mathrm{M}^{+}\right)$; Anal. Calcd for $\mathrm{C}_{14} \mathrm{H}_{20} \mathrm{O}_{2}$ : C, 76.33 ; H, 9.15. Found : C, 76.45 ; H, 9.09.

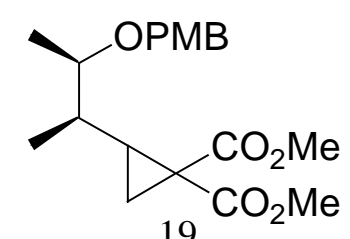


(2RS)-2-[(1R,2R)-2-(4-Methoxybenzyl)oxy-1-methylpropyl]cyclopropane-1,1-dimethyl dicarboxylate (38)

To a suspension of CuOTf $(31.8 \mathrm{mg}, 63.2 \mu \mathrm{mol})$ in toluene- $\mathrm{CH}_{2} \mathrm{Cl}_{2}(1: 1,20 \mathrm{~mL})$ were added alkene 37 (1.39 g, $6.32 \mathrm{mmol})$ and dimethyl diazomalonate ${ }^{6}(100 \mathrm{mg}, 0.632 \mathrm{mmol})$. The solution was plunged into an oil bath at $110{ }^{\circ} \mathrm{C}$ and the mixture was heated at reflux for 12 hours. The solvent was removed in vacuo to afford a green oil. Purification of the crude oil by flash chromatography (20\% EtOAc/hexane) provided cyclopropane 38 (179 $\mathrm{mg}, 81 \%, \mathrm{dr}=3: 1)$ as a colorless oil.

Data for 38: IR(neat) 1728, 1514, 1437, 1300, 1248, 1213, 1132, $1035 \mathrm{~cm}^{-1} ;{ }^{1} \mathrm{H} \mathrm{NMR}(600 \mathrm{MHz}$, $\left.\mathrm{CDCl}_{3}\right) \delta 7.26(\mathrm{~d}, J=7.2 \mathrm{~Hz}, 0.25 \times 2 \mathrm{H}), 7.25(\mathrm{~d}, J=9.0 \mathrm{~Hz}, 0.75 \times 2 \mathrm{H}), 6.87(\mathrm{dd}, J=1.8,7.2 \mathrm{~Hz}$, $0.25 \times 2 \mathrm{H}), 6.86(\mathrm{~d}, J=8.4 \mathrm{~Hz}, 0.75 \times 2 \mathrm{H}), 4.52(\mathrm{~d}, J=11.4 \mathrm{~Hz}, 0.25 \mathrm{H}), 4.51(\mathrm{~d}, J=11.4 \mathrm{~Hz}, 0.75 \mathrm{H})$, $4.37(\mathrm{~d}, J=11.4 \mathrm{~Hz}, 0.25 \mathrm{H}), 4.36(\mathrm{~d}, J=10.8 \mathrm{~Hz}, 0.75 \mathrm{H}), 3.80(\mathrm{~s}, 3 \mathrm{H}), 3.75$ (s, $0.25 \mathrm{x} 3 \mathrm{H}), 3.72$ (s, $0.25 \times 3 \mathrm{H}), 3.72$ (s, $0.75 \times 3 \mathrm{H}), 3.69$ (s, $0.75 \times 3 \mathrm{H}), 3.49$ (dq, J=3.6, 6.0 Hz, $0.75 \mathrm{H}), 3.47$ (dq, $J=4.2,6.0 \mathrm{~Hz}, 0.25 \mathrm{H}$ ), 2.10 (dt, $J=8.4,8.4 \mathrm{~Hz}, 0.75 \mathrm{H}), 1.94$ (td, $J=9.0,10.8 \mathrm{~Hz}, 0.25 \mathrm{H}$ ), 1.53 (dd, $J=4.8,8.4 \mathrm{~Hz}, 0.25 \mathrm{H}), 1.43(\mathrm{dd}, J=4.8,8.4 \mathrm{~Hz}, 0.75 \mathrm{H}), 1.40$ (dd, $J=4.2,9.0 \mathrm{~Hz}, 0.75 \mathrm{H}), 1.34$ (dd, $J=4.2,9.0 \mathrm{~Hz}, 0.25 \mathrm{H}) 1.26-1.19(\mathrm{~m}, 0.75 \mathrm{H}), 1.18-1.12(\mathrm{~m}, 0.25 \mathrm{H}), 1.19$ (d, J=6.0 Hz, 0.25 x $3 \mathrm{H})$, $1.11(\mathrm{~d}, J=6.0 \mathrm{~Hz}, 0.75 \times 3 \mathrm{H}), 1.03(\mathrm{~d}, J=6.6 \mathrm{~Hz}, 0.75 \times 3 \mathrm{H}), 1.00(\mathrm{~d}, J=6.6 \mathrm{~Hz}, 0.25 \times 3 \mathrm{H}) ;{ }^{13} \mathrm{C}$ NMR $\left(150 \mathrm{MHz}, \mathrm{CDCl}_{3}\right) \delta 171.07,170.63,169.19,169.04,159.23,159.16,131.31,131.15$, $129.37,129.35,113.88,113.83,77.84,77.42$, 70.97, 70.58, 55.43, 55.41, 52.73, 52.67, 52.61, 52.53, 38.45, 38.37, 34.76, 33.51, 33.17, 32.89, 21.46, 20.33, 17.23, 16.94, 14.88, 14.39 ; LRMS m/z $350\left(\mathrm{M}^{+}\right)$; Anal. Calcd for $\mathrm{C}_{19} \mathrm{H}_{26} \mathrm{O}_{6}: \mathrm{C}, 65.13 ; \mathrm{H}, 7.48$. Found : $\mathrm{C}, 64.85 ; \mathrm{H}, 7.52$.

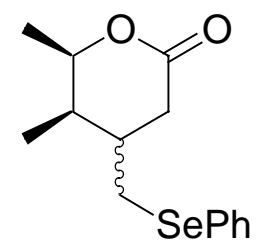

27

\section{(3RS,4R,5R)-4,5 -Dimethyl-3-phenylselenylmethylpentano-5-lactone (27)}

To a solution of cyclopropane $38(0.395 \mathrm{~g}, 1.13 \mathrm{mmol})$ in $\mathrm{MeCN}-\mathrm{H}_{2} \mathrm{O}(10: 1,10 \mathrm{~mL})$ was added ceric ammonium nitrate $(1.86 \mathrm{~g}, 3.39 \mathrm{mmol})$ in one portion. After $2 \mathrm{~h}$, the reaction was quenched by the addition of saturated $\mathrm{NaHCO}_{3}(15 \mathrm{~mL})$ and $\mathrm{NaHSO}_{3}(0.4 \mathrm{~g})$. The mixture was stirred vigorously for a further $15 \mathrm{~min}$ and then filtered. The filter cake was washed several times with EtOAc, and the combined filtrate and washings were extracted with EtOAc $(3 \times 50 \mathrm{~mL})$. The organic extracts were washed with brine, dried $\left(\mathrm{MgSO}_{4}\right)$ and concentrated to afford a crude oil. 
Purification of the crude oil by flash chromatography (33\% EtOAc/hexane) provided alcohols (240.8 $\mathrm{mg}, \mathrm{dr}=3: 1,93 \%)$ as a colorless oil.

Data for alcohols $(\mathrm{dr}=3: 1)$ : IR(neat) $3437,1728,1439,1298,1215,1134,912 \mathrm{~cm}^{-1} ;{ }^{1} \mathrm{H}$ NMR (400 MHz, $\left.\mathrm{CDCl}_{3}\right) \delta$ 3.85-3.78 (br, $\left.1 \mathrm{H}\right), 3.77$ (s, 0.25 x $3 \mathrm{H}$ ), 3.75 (s, $\left.0.75 \times 3 \mathrm{H}\right), 3.73(\mathrm{~s}, 3 \mathrm{H})$, 1.95 (dt, $J=8.0,8.0 \mathrm{~Hz}, 0.25 \mathrm{H}), 1.92$ (dt, $J=9.2,9.2 \mathrm{~Hz}, 0.75 \mathrm{H}), 1.88$ (br s, $0.75 \mathrm{H}), 1.79$ (br s, $0.25 \mathrm{H}), 1.57$ (dd, J=4.8, 8.0 Hz, 0.25 H), 1.44 (dd, J=4.8, 9.6 Hz, $1 \mathrm{H}), 1.39$ (dd, J=4.8, 8.0 Hz, $0.75 \mathrm{H}), 1.29-1.20(\mathrm{~m}, 0.75 \mathrm{H}), 1.22(\mathrm{~d}, J=6.4 \mathrm{~Hz}, 0.25$ x $3 \mathrm{H}), 1.15$ (d, J=6.4 Hz, 0.75 x $3 \mathrm{H}), 1.02$ $(\mathrm{d}, J=7.2 \mathrm{~Hz}, 0.75 \times 3 \mathrm{H}), 0.99$ (d, J=6.4 Hz, $0.25 \times 3 \mathrm{H}) ;{ }^{13} \mathrm{C} \mathrm{NMR}\left(100 \mathrm{MHz}, \mathrm{CDCl}_{3}\right) \delta 170.62$, 170.31, 169.11, 71.31, 70.11, 52.67, 52.62, 52.57, 52.52, 34.70, 33.29, 32.80, 31.64, 21.23, 20.90, 20.19, 19.67, 14.40, 13.88; LRMS $m / z, 231\left(\mathrm{M}^{+}+\mathrm{H}\right)$; HRMS calcd for $\mathrm{C}_{11} \mathrm{H}_{19} \mathrm{O}_{5}$ 231.1123, found : 231.1238 .

To a suspension of $(\mathrm{PhSe})_{2}(1.56 \mathrm{~g}, 5.00 \mathrm{mmol})$ in $\mathrm{EtOH}(15 \mathrm{~mL})$ was added $\mathrm{NaBH}_{4}(0.36 \mathrm{~g}, 9.52$ $\mathrm{mmol})$. After the yellow color had dissipated a solution of the alcohol $(0.24 \mathrm{~g})$ in EtOH $(5 \mathrm{~mL})$ was added. The mixture was heated at reflux and stirred for 16 hours. The reaction was diluted with $10 \% \mathrm{HCl}(15 \mathrm{~mL})$ and which was stirred for a further $5 \mathrm{~min}$ and then extracted with EtOAc $(3 \times 80$ $\mathrm{mL})$. The combined organic extracts were washed with saturated $\mathrm{NaHCO}_{3}(50 \mathrm{~mL})$, and brine $(50$ $\mathrm{mL})$, then dried $\left(\mathrm{MgSO}_{4}\right)$ and concentrated. Purification of the crude product by column chromatography (33\% EtOAc/hexane) provided lactones ( $0.29 \mathrm{~g}$, a mixture of three compounds). The mixture of lactones $(0.29 \mathrm{~g})$ and $\mathrm{LiI}(0.35 \mathrm{~g})$ in DMF $(5 \mathrm{~mL})$ was plunged into an oil bath at $150{ }^{\circ} \mathrm{C}$ and stirred for 12 hours. The solution was diluted with $\mathrm{H}_{2} \mathrm{O}(15 \mathrm{~mL})$ and then extracted with $\mathrm{Et}_{2} \mathrm{O}(3 \times 30 \mathrm{~mL})$. The combined organic extracts were washed with $\mathrm{H}_{2} \mathrm{O}$, and brine, then dried $\left(\mathrm{MgSO}_{4}\right)$ and concentrated. Purification of the crude oil by column chromatography (33\% EtOAc/hexane) provided an unseparated mixture of lactone $27(0.28 \mathrm{~g}, 83 \%)$ as a pale yellow oil.

Data for $27(\mathrm{dr}=3: 2)$ : IR(neat) 1732, 1240, 1209, 1096, 1003, 739, $692 \mathrm{~cm}^{-1} ;{ }^{1} \mathrm{H}$ NMR (600 $\mathrm{MHz}, \mathrm{CDCl}_{3}$ ) $\delta$ 7.52-7.49 (m, $\left.2 \mathrm{H}\right), 7.28-7.27$ (m, $\left.3 \mathrm{H}\right), 4.50$ (dq, J=3.6, 6.6 Hz, 0.6 H), 4.43 (dq, $J=2.4,6.6 \mathrm{~Hz}, 0.4 \mathrm{H}$ ), 3.03 (dd, $J=6.0,12.0 \mathrm{~Hz}, 0.6 \mathrm{H}$ ), 2.96 (dd, $J=7.2,12.6 \mathrm{~Hz}, 0.6 \mathrm{H}$ ), 2.89 (dd, $J=6.6,14.4 \mathrm{~Hz}, 0.4 \mathrm{H}), 2.84(\mathrm{dd}, J=7.2,12.6 \mathrm{~Hz}, 0.4 \mathrm{H}), 2.74$ (dd, $J=5.4,18.0 \mathrm{~Hz}, 0.4 \mathrm{H}), 2.67$ (dd, $J=6.6,16.8 \mathrm{~Hz}, 0.6 \mathrm{H}), 2.37$ (dd, $J=9.6,16.2 \mathrm{~Hz}, 0.6 \mathrm{H}), 2.27-2.21(\mathrm{~m}, 0.4 \mathrm{H}), 2.17$ (dd, $J=12.6$, $18.0 \mathrm{~Hz}, 0.4 \mathrm{H}), 2.08-2.04$ (m, 0.4 H), 1.96-1.86 (m, 0.6 x 2 H), 1.33 (d, J=6.6 Hz, 0.4 x 3 H), 1.28 $(\mathrm{d}, J=6.6 \mathrm{~Hz}, 0.6 \times 3 \mathrm{H}), 0.95(\mathrm{~d}, J=7.2 \mathrm{~Hz}, 0.6 \times 3 \mathrm{H}), 0.83(\mathrm{~d}, J=7.2 \mathrm{~Hz}, 0.4 \times 3 \mathrm{H}) ;{ }^{13} \mathrm{C} \mathrm{NMR}$ $\left(100 \mathrm{MHz}, \mathrm{CDCl}_{3}\right) \delta 172.06,170.39,133.18,133.09,133.08,129.36,129.29,129.14,127.46$, $127.45,127.44,80.28,75.86,37.34,37.19,36.86,34.33$, 34.24, 33.83, 32.28, 31.03, 18.49, 16.98, 13.91, 4.20; LRMS m/z $298\left(\mathrm{M}^{+}\right)$; HRMS calcd for $\mathrm{C}_{14} \mathrm{H}_{18} \mathrm{O}_{2} \mathrm{Se} 298.0472$, found : 298.0470.

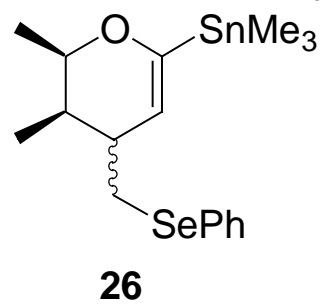


$(2 R, 3 R, 4 R S)-3,4-D i h y d r o-2,3$-dimethyl-4-phenylselenylmethyl-

\section{6-trimethylstannyl-2H-pyran (26)}

To a $-78{ }^{\circ} \mathrm{C}$ solution of lactone $27(114.3 \mathrm{mg}, 0.384 \mathrm{mmol})$ in THF $(2.5 \mathrm{~mL})$ was added KHMDS $(1.00 \mathrm{~mL}, 0.5 \mathrm{M}$ in toluene, $0.500 \mathrm{mmol})$ dropwise over $20 \mathrm{~min}$. After $15 \mathrm{~min}$, HMPA $(0.100 \mathrm{~mL}$, $0.575 \mathrm{mmol}$ ) was added and the mixture stirred for 2 hours at that temperature. A solution of $\mathrm{PhNTf}_{2}$ (0.164 mg, $0.460 \mathrm{mmol}$, recrystallized from $\mathrm{CH}_{2} \mathrm{Cl}_{2}$-hexane) in THF (2 mL) was added dropwise and the mixture stirred at $0{ }^{\circ} \mathrm{C}$ for 1 hour and at $\mathrm{rt}$ for 2 hours. The solvent was removed to give an oily residue, which was dissolved in $\mathrm{Et}_{2} \mathrm{O}(10 \mathrm{~mL})$ and $\mathrm{H}_{2} \mathrm{O}(10 \mathrm{~mL})$. The separated aqueous phase was extracted with $\mathrm{Et}_{2} \mathrm{O}(3 \times 20 \mathrm{~mL})$. The combined organic extracts were washed with brine $(10 \mathrm{~mL})$, dried $\left(\mathrm{MgSO}_{4}\right)$ and concentrated to afford a crude enol triflate $(163 \mathrm{mg})$, which was used immediately in the next step.

To a solution of the crude enol triflate $(163 \mathrm{mg})$ in THF $(15 \mathrm{~mL})$ was added a solution of $\left(\mathrm{Me}_{3} \mathrm{Sn}\right)_{2}$ in THF $(0.580 \mathrm{~mL}, 1.0 \mathrm{M}, 0.580 \mathrm{mmol})$ followed by $\mathrm{Pd}\left(\mathrm{PPh}_{3}\right)_{4}(22.2 \mathrm{mg}, 19.2 \mu \mathrm{mol})$ and $\mathrm{LiCl}$ (162.6 mg, $3.84 \mathrm{mmol})$. The mixture was stirred under reflux for 12 hours. Saturated $\mathrm{NaHCO}_{3}(10$ $\mathrm{mL}$ ) was added to the mixture and the phases were separated. The aqueous phase was further extracted with $\mathrm{Et}_{2} \mathrm{O}(3 \times 20 \mathrm{~mL})$. The combined organic extracts were washed with brine $(20 \mathrm{~mL})$, dried $\left(\mathrm{MgSO}_{4}\right)$ and concentrated to give a crude oil. Purification of the crude oil by chromatography on alumina deactivated by $5 \%$ water eluting with petroleum ether provided dihydropyran 26 (143.5 $\mathrm{mg}, 84 \%$ ) as a colorless oil.

Data for 26 (dr = 3:1): IR(neat) 2970, 2922, 2876, 1603, 1578, 1477, 1437, 1379, 1252, 1070, $1022, \mathrm{~cm}^{-1} ;{ }^{1} \mathrm{H}$ NMR (400 MHz, $\left.\mathrm{CDCl}_{3}\right) \delta$ 7.50-7.47 (m, $\left.2 \mathrm{H}\right)$, 7.33-7.19 (m, $\left.3 \mathrm{H}\right), 4.73-4.64$ (m, $0.75 \mathrm{H}), 4.49-4.41(\mathrm{~m}, 0.25 \mathrm{H}), 3.95(\mathrm{dq}, J=1.6,6.4 \mathrm{~Hz}, 0.25 \mathrm{H}), 3.78(\mathrm{dq}, J=2.4,6.4 \mathrm{~Hz}, 0.75 \mathrm{H})$, 2.96 (dd, $J=6.0,12.4 \mathrm{~Hz}, 1 \mathrm{H}), 2.84(\mathrm{dd}, J=8.0,11.2 \mathrm{~Hz}, 0.75+0.25$ x $2 \mathrm{H}), 2.73-2.66(\mathrm{~m}, 0.25 \mathrm{H})$, 1.93-1.88 (m, 0.75 H), 1.85-1.77 (m, $1 \mathrm{H}), 1.18(\mathrm{~d}, J=6.0 \mathrm{~Hz}, 0.25$ x $3 \mathrm{H}), 1.14$ (d, J=6.8 Hz, 0.75 x $3 \mathrm{H}), 0.82(\mathrm{~d}, J=7.2 \mathrm{~Hz}, 0.75 \times 3 \mathrm{H}), 0.75(\mathrm{~d}, J=6.8 \mathrm{~Hz}, 0.25$ x $3 \mathrm{H}), 0.13(\mathrm{~s}, 9 \mathrm{H}) ;{ }^{13} \mathrm{C}$ NMR $(100$ $\left.\mathrm{MHz}, \mathrm{CDCl}_{3}\right) \delta 162.48,132.59,132.50,130.60,128.95,128.92,126.65,125.43,112.64,75.55$, 70.60, 39.77, 38.44, 35.08, 34.80, 34.27, 33.95, 31.49, 30.38, 18.57, 17.51, 13.08, 5.32, -9.64; LRMS $m / z 446\left(\mathrm{M}^{+}\right)$; HRMS calcd for $\mathrm{C}_{17} \mathrm{H}_{26} \mathrm{OSeSn} 446.0171$, found :.446.0154.

Data for the major isomer of $2: \mathrm{mp}<30{ }^{\circ} \mathrm{C} ;[\alpha]^{26}{ }_{\mathrm{D}}=+51.86^{\circ}\left(\mathrm{c} 1.10, \mathrm{CHCl}_{3}\right)$; IR (neat) 2970, 2920, 2876, 1578, 1477, 1456, 1437, 1379, 1252, 1070, 1022, $\mathrm{cm}^{-1} ;{ }^{1} \mathrm{H}$ NMR (400 MHz, $\left.\mathrm{CDCl}_{3}\right)$ $\delta$ 7.50-7.47 (m, $2 \mathrm{H}), 7.26-7.20$ (m, $3 \mathrm{H}), 4.74-4.64(\mathrm{~m}, 1 \mathrm{H}), 3.78$ (dq, J=2.4, $6.4 \mathrm{~Hz}, 1 \mathrm{H}), 2.97$ $(\mathrm{dd}, J=6.0,12.4 \mathrm{~Hz}, 1 \mathrm{H}), 2.84(\mathrm{dd}, J=8.8,12.0 \mathrm{~Hz}, 1 \mathrm{H}), 1.93-1.88(\mathrm{~m}, 1 \mathrm{H}), 1.84-1.77$ (m, $1 \mathrm{H})$, $1.14(\mathrm{~d}, J=6.4 \mathrm{~Hz}, 3 \mathrm{H}), 0.82(\mathrm{~d}, J=6.8 \mathrm{~Hz}, 3 \mathrm{H}), 0.13(\mathrm{~s}, 9 \mathrm{H}) ;{ }^{13} \mathrm{C} \mathrm{NMR}\left(100 \mathrm{MHz}, \mathrm{CDCl}_{3}\right) \delta$ $162.47,132.59$, 130.60, 128.91, 126.65, 125.42, 112.63, 70.59, 39.77, 35.08, 34.80, 30.37, 17.50, $13.07,-9.66$.

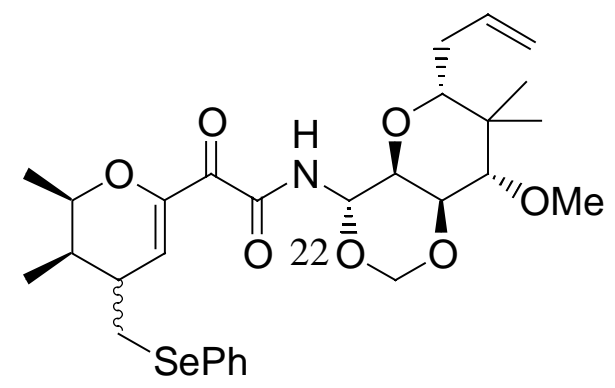


$(1 S, 5 R, 6 S, 8 R, 10 S)-10-M e t h o x y-9,9-d i m e t h y l-5-\{[(2 R, 3 R, 4 R S)-$

2,3-dimethyl-4-phenylselenylmethyl-3,4-dihydro-2H-pyran-6-yl]oxoethanamido\}-8-(prop-2 -enyl)-2,4,7-trioxabicyclo[4.4.0]decane (39)

To a $-78{ }^{\circ} \mathrm{C}$ solution of left segment $26(51.6 \mathrm{mg}, 0.116 \mathrm{mmol})$ in THF $(0.65 \mathrm{~mL})$ was added BuLi $(0.20 \mathrm{~mL}, 0.57 \mathrm{M}$ in THF, $0.12 \mathrm{mmol})$ dropwise over $10 \mathrm{~min}$. After $15 \mathrm{~min}$ TMEDA $(0.11 \mathrm{~mL})$ was added and the solution was stirred for $30 \mathrm{~min}$, and then a cold solution of right segment 2 (22.9 mg, $66.8 \mu \mathrm{mol})$ in THF $(0.25 \mathrm{~mL} \times 2)$ was added via cannula. The mixture was stirred for 2.5 hours at that temperature before being poured onto ice-cooled saturated aqueous $\mathrm{NH}_{4} \mathrm{Cl}(7 \mathrm{~mL})$ and stirred vigorously for $10 \mathrm{~min}$. The separated aqueous phase was further extracted with $\mathrm{CH}_{2} \mathrm{Cl}_{2}(30 \mathrm{~mL} x$ $3)$. The combined organic extracts were dried $\left(\mathrm{Na}_{2} \mathrm{SO}_{4}\right)$ and concentrated to give a crude yellow oil (71.5 mg). Purification of the crude oil by flash chromatography (33\% EtOAc/hexane) provided the title compound $\mathbf{3 9}(19.6 \mathrm{mg}, 50 \%)$ as a colorless oil.

Data for $39(\mathrm{dr}=12.5: 1)$ : IR(neat) 3364, 2878, 1695, 1674, 1522, 1107, 1074, 1024, 739, 694 $\mathrm{cm}^{-1} ;{ }^{1} \mathrm{H}$ NMR (400 MHz, $\mathrm{CDCl}_{3}$ ) $\delta$ 7.54-7.47 (m, $\left.3 \mathrm{H}\right), 7.29-7.23$ (m, $\left.3 \mathrm{H}\right), 7.14$ (dd, J=1.2, 5.0 $\mathrm{Hz}, 0.93 \mathrm{H}), 7.07(\mathrm{dd}, J=1.6,2.2 \mathrm{~Hz}, 0.07 \mathrm{H}), 5.71(\mathrm{dd}, J=9.5,9.5 \mathrm{~Hz}, 0.07 \mathrm{H}), 5.70(\mathrm{dd}, J=9.5,9.5$ $\mathrm{Hz}, 0.93 \mathrm{H}), 5.61(\mathrm{tdd}, J=6.8,10.0,16.8 \mathrm{~Hz}, 1 \mathrm{H}), 5.16$ (d, J=7.1 Hz, $1 \mathrm{H}), 4.89$ (d, J=6.8 Hz, $1 \mathrm{H})$, $4.86(\mathrm{dd}, J=1.6,9.5 \mathrm{~Hz}, 0.07 \mathrm{H}), 4.78$ (dd, $J=1.2,10.0 \mathrm{~Hz}, 0.93 \mathrm{H}), 4.25$ (dd, $J=6.6,10.2 \mathrm{~Hz}, 1 \mathrm{H})$, 4.09 (dq, $J=1.2,6.4 \mathrm{~Hz}, 0.07 \mathrm{H}), 4.00$ (dq, $J=2.2,6.3 \mathrm{~Hz}, 0.93 \mathrm{H}), 3.92(\mathrm{dd}, J=6.7,9.8 \mathrm{~Hz}, 0.07 \mathrm{H})$, 3.91 (dd, J=6.6, $9.8 \mathrm{~Hz}, 0.93 \mathrm{H}), 3.57$ (s, $3 \mathrm{H}), 3.46$ (d, J=10.2 Hz, $0.07 \mathrm{H}), 3.45$ (d, J=10.2 Hz, $0.93 \mathrm{H}), 3.29$ (dd, $J=2.0,10.0 \mathrm{~Hz}, 0.07 \mathrm{H}), 3.27$ (dd, $J=2.0,10.0 \mathrm{~Hz}, 0.93 \mathrm{H}), 3.06$ (dd, $J=5.9,12.4$ $\mathrm{Hz}, 0.93 \mathrm{H}), 3.03-2.92$ (m, 0.07 x $2 \mathrm{H}), 2.88$ (dd, $J=8.5,12.7 \mathrm{~Hz}, 0.93 \mathrm{H}), 2.89-2.81$ (m, $0.07 \mathrm{H})$, 2.88 (dd, $J=8.5,12.7 \mathrm{~Hz}, 0.93 \mathrm{H}), 2.27-2.21$ (m, $1 \mathrm{H}), 2.13$ (ddm, $J=6.6,12.4 \mathrm{~Hz}, 1 \mathrm{H}), 2.06-1.95$ $(\mathrm{m}, 2 \mathrm{H}), 1.38(\mathrm{~d}, J=6.6 \mathrm{~Hz}, 0.07 \times 3 \mathrm{H}), 1.31(\mathrm{~d}, J=6.6 \mathrm{~Hz}, 0.93 \times 3 \mathrm{H}), 1.01(\mathrm{~s}, 3 \mathrm{H}), 0.88(\mathrm{~s}, 3 \mathrm{H})$, $0.86(\mathrm{~d}, J=7.2 \mathrm{~Hz}, 0.93 \times 3 \mathrm{H}) ;{ }^{13} \mathrm{C} \mathrm{NMR}\left(100 \mathrm{MHz}, \mathrm{CDCl}_{3}\right)$ for the major isomer $\delta 179.84$, $160.43,147.47,135.44,133.29,129.38,129.14,127.35,124.37,116.24,86.72,79.40,78.77$, 74.61, 73.81, 72.11, 70.24, 61.83, 41.66, 40.01, 34.34, 33.24, 32.78, 23.19, 16.99, 13.54, 13.20; LRMS m/z $593\left(\mathrm{M}^{+}\right)$; HRMS calcd for $\mathrm{C}_{29} \mathrm{H}_{39} \mathrm{NO}_{7} \mathrm{Se}$ 593.1892, found : 593.1901 .

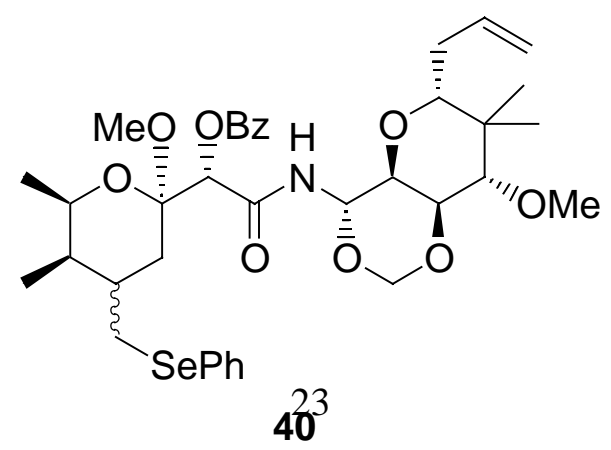


(4RS)-7-Benzoyl-4-phenylselenylmethyl-15-(prop-2-enyl)-mycalamide A

To a $-90{ }^{\circ} \mathrm{C}$ solution of ketone $39(21.3 \mathrm{mg}, 35.9 \mu \mathrm{mol})$ in $(1.5 \mathrm{~mL})$ was added $\mathrm{LiBH}(s \mathrm{Bu})_{3}(0.47$ $\mathrm{mL}, 0.23 \mathrm{M}$ in THF, $0.108 \mathrm{mmol}$ ) dropwise over $20 \mathrm{~min}$. After stirring at $-90{ }^{\circ} \mathrm{C}$ for $15 \mathrm{~min}$ the reaction was quenched by the addition of brine $(3 \mathrm{~mL})$ and $\mathrm{CH}_{2} \mathrm{Cl}_{2}(3 \mathrm{~mL})$. The mixture was stirred vigorously for a further $20 \mathrm{~min}$. The separated aqueous phase was extracted with $\mathrm{CH}_{2} \mathrm{Cl}_{2}$ (10 mL x 3), dried $\left(\mathrm{Na}_{2} \mathrm{SO}_{4}\right)$ and concentrated to give a colorless oil, which was used immediately in the next step. The residue was dissolved in a mixture of $\mathrm{CH}_{2} \mathrm{Cl}_{2}(2.3 \mathrm{~mL})$ and $\mathrm{MeOH}(0.2 \mathrm{~mL})$ to which CSA ( $2 \mathrm{mg}$ ) was added. The mixture was stirred for 18 hours before $\mathrm{K}_{2} \mathrm{CO}_{3}(8 \mathrm{mg})$ was added. The solution was then stirred for $40 \mathrm{~min}$ and poured onto saturated aqueous $\mathrm{NaHCO}_{3}(3$ $\mathrm{mL})$. The phases were separated and the aqueous phase was further extracted with $\mathrm{CH}_{2} \mathrm{Cl}_{2}(10 \mathrm{~mL}$ $x 3)$. The combined organic extracts were dried $\left(\mathrm{Na}_{2} \mathrm{SO}_{4}\right)$ and concentrated to give a yellow oil, which was used immediately in the next step. To a solution of the crude oil in $\mathrm{CH}_{2} \mathrm{Cl}_{2}(1 \mathrm{~mL})$ were added DMAP ( $8.8 \mathrm{mg}, 72 \mu \mathrm{mol}),{ }^{i} \operatorname{Pr}_{2} \mathrm{NEt}(63 \mu \mathrm{L}, 0.36 \mathrm{mmol})$ and benzoyl chloride $(12 \mu \mathrm{L}, 0.10$ $\mathrm{mmol})$. The mixture was stirred for 1 hour at $\mathrm{rt}$, and then $\mathrm{MeOH}(0.05 \mathrm{~mL})$ was added. After stirring for $10 \mathrm{~min}$, brine $(3 \mathrm{~mL})$ was added and the mixture was extracted with $\mathrm{CH}_{2} \mathrm{Cl}_{2}(10 \mathrm{~mL} \times 3)$. The combined organic extracts were dried $\left(\mathrm{Na}_{2} \mathrm{SO}_{4}\right)$ and concentrated to give a yellow solid. Purification of the crude solid by flash chromatography (33\% EtOAc/hexane) provided benzoates (19.8 mg, 75\% for 3 steps, a mixture of 5 diastereoisomers) as a colorless solid. The diastereoisomers were separated by column chromatography (33\% EtOAc/hexane) to give the title compounds 40 (11.0 mg, a 5.4:1 mixture of diastereoisomers at C4, $42 \%$ for 3 steps).

Data for $40(\mathrm{dr}=13: 1)$ : $\mathrm{mp} 70-75^{\circ} \mathrm{C}$; IR(KBr) 3362, 1732, 1699, 1522, 1269, 1107, 1034, 739, $710 \mathrm{~cm}^{-1} ;{ }^{1} \mathrm{H}$ NMR (600 MHz, $\mathrm{C}_{6} \mathrm{D}_{6}$ referenced to $\left.7.16 \mathrm{ppm}\right) \delta 8.31$ (ddd, $J=1.8,1.8,7.2 \mathrm{~Hz}, 2 \mathrm{H}$ ), 7.50-7.48 (m, $0.93 \times 2 \mathrm{H}), 7.48-7.46(\mathrm{~m}, 0.07 \times 2 \mathrm{H}), 7.31(\mathrm{~d}, J=9.6 \mathrm{~Hz}, 0.93 \mathrm{H}), 7.06-6.91(\mathrm{~m}, 6$ H), 6.08-6.02 (m, 0.07 H), 6.00-5.95 (m, $0.93 \mathrm{H}), 5.94(\mathrm{~s}, 0.07 \mathrm{H}), 5.93$ (t, J=10.2 Hz, $0.07 \mathrm{H})$, 5.93 (t, $J=10.2 \mathrm{~Hz}, 0.93 \mathrm{H}), 5.89$ (s, $0.93 \mathrm{H}), 4.97$ (dddd, $J=1.8,1.8,3.6,6.7 \mathrm{~Hz}, 0.93 \mathrm{H}), 4.95$ (dd, $J=1.2,2.1 \mathrm{~Hz}, 0.93 \mathrm{H}), 4.60(\mathrm{~d}, J=7.2 \mathrm{~Hz}, 0.07 \mathrm{H}), 4.58(\mathrm{~d}, J=7.2 \mathrm{~Hz}, 0.93 \mathrm{H}), 4.54(\mathrm{~d}, J=7.2 \mathrm{~Hz}$, $0.07 \mathrm{H}), 4.52(\mathrm{~d}, J=7.2 \mathrm{~Hz}, 0.93 \mathrm{H}), 4.32(\mathrm{dd}, J=6.8,10.3 \mathrm{~Hz}, 1 \mathrm{H}), 4.29$ (dd, J=6.8, $10.4 \mathrm{~Hz}, 1 \mathrm{H})$, 3.77 (dd, $J=6.6,10.2 \mathrm{~Hz}, 0.93 \mathrm{H}), 3.73$ (dq, $J=2.4,6.6 \mathrm{~Hz}, 0.93 \mathrm{H}), 3.81$ (dd, $J=6.8,9.7 \mathrm{~Hz}, 0.07 \mathrm{H}$ ), 3.56-3.54 (m, 0.07 x $2 \mathrm{H}), 3.54$ (dd, $J=3.0,10.2 \mathrm{~Hz}, 0.93 \mathrm{H}), 3.31$ (dd, $J=7.2,12.6 \mathrm{~Hz}, 0.93 \mathrm{H}$ ), 3.27 (s, $0.07 \times 3 \mathrm{H}), 3.26$ (s, $0.93 \times 3 \mathrm{H}), 3.16(\mathrm{dd}, J=9.0,12.6 \mathrm{~Hz}, 0.93 \mathrm{H}), 3.07$ (d, J=10.2 Hz, $0.93 \mathrm{H}), 3.06$ (d, J=10.8 Hz, $0.07 \mathrm{H}), 2.89$ (s, 0.07 x $3 \mathrm{H}), 2.84$ (dd, J=5.8, $11.9 \mathrm{~Hz}, 0.07 \mathrm{H}), 2.82$ (s, $0.93 \times 3 \mathrm{H}), 2.79(\mathrm{dd}, J=11.9,14.4 \mathrm{~Hz}, 0.07 \mathrm{H}), 2.47-2.38(\mathrm{~m}, 0.07 \mathrm{H}), 2.29$ (dd, $J=3.6,13.5 \mathrm{~Hz}$, $0.07 \mathrm{H}), 2.27$ (dd, $J=6.0,14.4 \mathrm{~Hz}, 0.93 \mathrm{H}), 2.24$ (mddd, $J=1.8,2.4,12.6 \mathrm{~Hz}, 0.093 \mathrm{H}), 2.17-2.11$ (m, $0.07 \mathrm{H}$ ), 2.09 (qdd, $J=3.0,5.4,15.0 \mathrm{~Hz}, 0.93 \mathrm{H}$ ), 2.04 (mdd, $J=7.8,15.8 \mathrm{~Hz}, 0.07 \mathrm{H}$ ), 2.01-1.95 (m, $0.93 \mathrm{H}), 1.90-1.86(\mathrm{~m}, 0.93 \mathrm{H}), 1.85(\mathrm{t}, J=13.0 \mathrm{~Hz}, 0.07 \mathrm{H}), 1.63-1.60(\mathrm{~m}, 0.07 \mathrm{H}), 1.60-1.55(\mathrm{~m}$, $0.93 \mathrm{H}), 0.94$ (d, J=7.2 Hz, $0.93 \times 3 \mathrm{H}), 0.86$ (s, $0.07 \times 3 \mathrm{H}), 0.85$ (d, J=6.6 Hz, $0.93 \times 3 \mathrm{H}), 0.84$ (s, $0.93 \times 3 \mathrm{H}), 0.84(\mathrm{~d}, J=7.8 \mathrm{~Hz}, 0.07 \times 3 \mathrm{H}), 0.79$ (d, $J=7.2 \mathrm{~Hz}, 0.07 \times 3 \mathrm{H}), 0.78(\mathrm{~s}, 0.07 \times 3 \mathrm{H}), 0.77$ 
$(\mathrm{s}, 0.93 \times 3 \mathrm{H}) ;{ }^{13} \mathrm{C} \mathrm{NMR}\left(150 \mathrm{MHz}, \mathrm{CDCl}_{3}\right)$ for the major isomer $\delta 166.40,165.58,137.10$, $133.30,133.16,131.00,130.41,130.29$, 129.26, 128.61, 126.95, 115.99, 99.92, 86.76, 78.98, 78.53, 75.35, 74.41, 73.03, 72.08, 64.73, 61.28, 47.51, 41.58, 38.24, 35.08, 34.24, 34.20, 28.95, 23.11, 18.28, 13.63, 13.10; LRMS $m / z 731\left(\mathrm{M}^{+}\right)$; HRMS calcd for $\mathrm{C}_{37} \mathrm{H}_{49} \mathrm{NO}_{9} \mathrm{Se}$ 731.2573, found : 731.2554 .

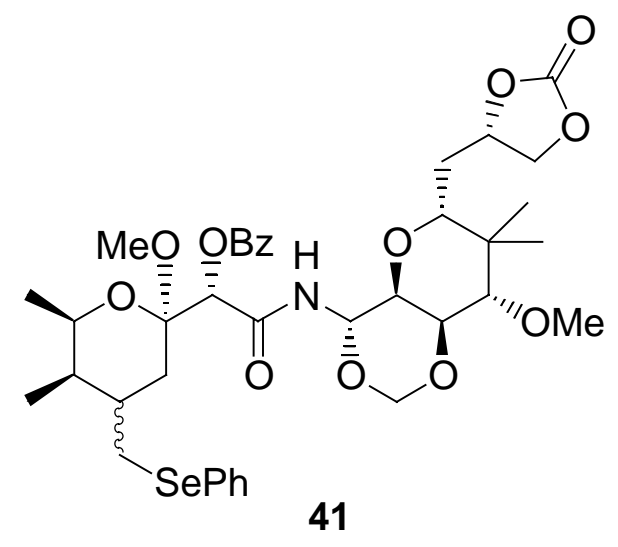

(4RS)-7-Benzoyl-17,18-O-carbonyldioxy-4-phenylselenylmethylmycalamide A (41)

To a well stirred suspension of (DHQ) ${ }_{2} \mathrm{PYR}(3.6 \mathrm{mg}, 4.1 \mu \mathrm{mol}), \mathrm{K}_{3} \mathrm{Fe}(\mathrm{CN})_{6}(13.5 \mathrm{mg}, 41.0 \mu \mathrm{mol})$ and $\mathrm{K}_{2} \mathrm{CO}_{3}(5.7 \mathrm{mg}, 4.1 \mu \mathrm{mol})$ in ${ }^{t} \mathrm{BuOH}-\mathrm{H}_{2} \mathrm{O}(1: 1,1 \mathrm{~mL})$ was added $\mathrm{OsO}_{4}(1 \%$ in water, $5 \mu \mathrm{L}, 0.1$ $\mu \mathrm{mol})$ at $0{ }^{\circ} \mathrm{C}$. The solution was stirred for $2 \mathrm{~h}$ and poured onto alkene $40(3.0 \mathrm{mg}, 4.1 \mu \mathrm{mol})$ in a 10 $\mathrm{mL}$ flask at $-10{ }^{\circ} \mathrm{C}$. The mixture was stirred for 4 hours at $-10{ }^{\circ} \mathrm{C}$ before saturated aqueous $\mathrm{Na}_{2} \mathrm{SO}_{3}(2 \mathrm{~mL})$ was added. The resulting colorless solution was extracted with EtOAc (10 mL x 3). The combined organic extracts were dried $\left(\mathrm{Na}_{2} \mathrm{SO}_{4}\right)$ and concentrated to give a white solid (13 mg), which was used immediately in the next step.

To a solution of the crude diol $(13 \mathrm{mg})$ in $\mathrm{CH}_{2} \mathrm{Cl}_{2}(1 \mathrm{~mL})$ were added $\mathrm{Et}_{3} \mathrm{~N}(5.7 \mu \mathrm{L}, 41.0 \mu \mathrm{mol})$ and a solution of triphosgene $(4.9 \mathrm{mg}, 16.4 \mu \mathrm{mol})$ in $\mathrm{CH}_{2} \mathrm{Cl}_{2}(0.3 \mathrm{~mL})$. The mixture was stirred for 2 hours and poured onto a mixture of $\mathrm{CH}_{2} \mathrm{Cl}_{2}(2 \mathrm{~mL})$ and saturated aqueous $\mathrm{NaHCO}_{3}(2 \mathrm{~mL})$. The phases were separated and the aqueous phase was further extracted with $\mathrm{CH}_{2} \mathrm{Cl}_{2}(4 \mathrm{~mL} \times 3)$. The combined organic extracts were dried $\left(\mathrm{Na}_{2} \mathrm{SO}_{4}\right)$ and concentrated to give a crude oil. Purification of the crude oil by flash chromatography (40\% EtOAc/hexane) provided carbonates $(3.1 \mathrm{mg}, 94 \%$ for 2 steps, $\mathrm{C} 17 \alpha: \mathrm{C} 17 \beta=4.8: 1)$ as a white oil. The diastereoisomers were separated by HPLC $\left(\mathrm{SiO}_{2}, 30 \% \mathrm{EtOAc} / \mathrm{hexane}\right)$ to afford carbonate $41(1.8 \mathrm{mg})$.

Data for 41 (C4 $\alpha: \mathrm{C} 4 \beta=11: 1$ ): IR(neat) 3352, 2959, 2930, 1799, 1732, 1699, 1271, 1124, 1107, 1092, 1069, 1036, $712 \mathrm{~cm}^{-1} ;{ }^{1} \mathrm{H}$ NMR $\left(400 \mathrm{MHz}, \mathrm{C}_{6} \mathrm{D}_{6}\right.$ referenced to $\left.7.15 \mathrm{ppm}\right) \delta 8.30(\mathrm{dd}, J=2.8$, $7.6 \mathrm{~Hz}, 2 \mathrm{H}), 7.54(\mathrm{~d}, J=7.1 \mathrm{~Hz}, 0.92 \times 2 \mathrm{H}), 7.53(\mathrm{~d}, J=8.3 \mathrm{~Hz}, 0.08 \times 2 \mathrm{H}), 7.31(\mathrm{~d}, J=11.0 \mathrm{H}, 1 \mathrm{H})$, 7.12-6.95 (m, $6 \mathrm{H}), 5.79$ (s, $0.08 \mathrm{H}), 5.76$ (s, $0.92 \mathrm{H}), 4.50$ (t, J=9.5 Hz, $1 \mathrm{H}), 4.81-4.74$ (m, 0.08 x $2 \mathrm{H}), 4.76-4.69(\mathrm{~m}, 0.92 \times 2 \mathrm{H}), 4.61(\mathrm{t}, J=8.5 \mathrm{~Hz}, 0.08 \mathrm{H}), 4.54(\mathrm{t}, J=8.3 \mathrm{~Hz}, 0.92 \mathrm{H}), 4.52$ (d, $J=6.8 \mathrm{~Hz}, 0.92 \mathrm{H}), 4.51(\mathrm{~d}, J=6.9 \mathrm{~Hz}, 0.08 \mathrm{H}), 4.40$ (d, $J=6.8 \mathrm{~Hz}, 0.92 \mathrm{H}), 4.39$ (d, J=6.9 Hz, 0.08 H), 4.19 (dd, $J=7.1,10.7 \mathrm{~Hz}, 0.08 \mathrm{H}), 4.18$ (dd, $J=6.8,10.5 \mathrm{~Hz}, 0.08 \mathrm{H}), 3.68(\mathrm{dd}, J=7.1,10.0 \mathrm{~Hz}$, $0.08 \mathrm{H}), 3.71(\mathrm{dq}, J=2.4,6.2 \mathrm{~Hz}, 0.92 \mathrm{H}), 3.68(\mathrm{dd}, J=7.1,10.0 \mathrm{~Hz}, 0.08 \mathrm{H}), 3.54(\mathrm{dd}, J=8.0,8.0 \mathrm{~Hz}$, 
$0.08 \mathrm{H}$ ), 3.54 (dd, $J=6.2,8.3 \mathrm{~Hz}, 0.08 \mathrm{H}), 3.53$ (dd, $J=6.1,8.5 \mathrm{~Hz}, 0.92 \mathrm{H}), 3.24$ (s, $3 \mathrm{H}), 3.23$ (dd, $J=6.6,12.4 \mathrm{~Hz}, 0.92 \mathrm{H}$ ), 3.14 (dd, $J=9.0,12.4 \mathrm{~Hz}, 0.92 \mathrm{H}), 3.09$ (d, $J=10.5 \mathrm{~Hz}, 0.92 \mathrm{H}$ ), 3.06 (d, $J=10.1 \mathrm{~Hz}, 0.08 \mathrm{H}), 2.83(\mathrm{dd}, J=6.5,11.9 \mathrm{~Hz}, 0.08 \mathrm{H}), 2.79-2.77$ (m, $0.08 \mathrm{H}), 2.82(\mathrm{~s}, 0.08 \times 3 \mathrm{H})$, $2.78(\mathrm{~s}, 0.92 \times 3 \mathrm{H}), 2.38-2.30(\mathrm{~m}, 0.08 \mathrm{H}), 2.24(\mathrm{dd}, J=11.3,14.8 \mathrm{~Hz}, 0.08 \mathrm{H}), 2.25$ (dd, $J=2.8$, $11.7 \mathrm{~Hz}, 0.92 \mathrm{H}), 2.19$ (dd, J=3.2, $13.0 \mathrm{~Hz}, 0.08 \mathrm{H}$ ), 2.04 (dd, J=6.1, 14.1 Hz, 0.92 H), 1.96-1.88 (m, 1 H),1.65-1.54 (m, 2 H), 1.16 (dd, J=10.0, $13.9 \mathrm{~Hz}, 1 \mathrm{H}), 0.88$ (d, J=7.1 Hz, 0.92 x 3 H), 0.83 $(\mathrm{d}, J=6.3 \mathrm{~Hz}, 0.92 \times 3 \mathrm{H}), 0.82(\mathrm{~d}, J=6.9 \mathrm{~Hz}, 0.08 \times 3 \mathrm{H}), 0.72(\mathrm{~d}, J=7.1 \mathrm{~Hz}, 0.08 \times 3 \mathrm{H}), 0.66$ (s, $3 \mathrm{H}), 0.82(\mathrm{~d}, J=6.9 \mathrm{~Hz}, 0.08 \times 3 \mathrm{H}), 0.72(\mathrm{~d}, J=7.1 \mathrm{~Hz}, 0.08 \times 3 \mathrm{H}), 0.66(\mathrm{~s}, 3 \mathrm{H}), 0.54(\mathrm{~s}, 3 \mathrm{H}) ;{ }^{13} \mathrm{C}$ NMR (150 MHz, $\mathrm{C}_{6} \mathrm{D}_{6}$ referenced to $128 \mathrm{ppm}$ ) for the major isomer $\delta 166.84,165.49,133.80$, $133.28,132.64,130.77,130.10,129.77,129.45$, 129.01, 128.44, 127.34, 127.19, 99.89, 86.83, 78.30, 74.92, 74.80, 74.73, 72.74, 72.56, 69.88, 64.91, 62.75, 61.39, 47.73, 41.27, 38.45, 34.78, 34.38, 33.85, 30.56, 28.67, 22.79, 18.28, 13.03; LRMS $\mathrm{m} / \mathrm{z} 791\left(\mathrm{M}^{+}\right)$; HRMS calcd for $\mathrm{C}_{38} \mathrm{H}_{49} \mathrm{NO}_{12} \mathrm{Se} 791.2420$, found : 791.2412.

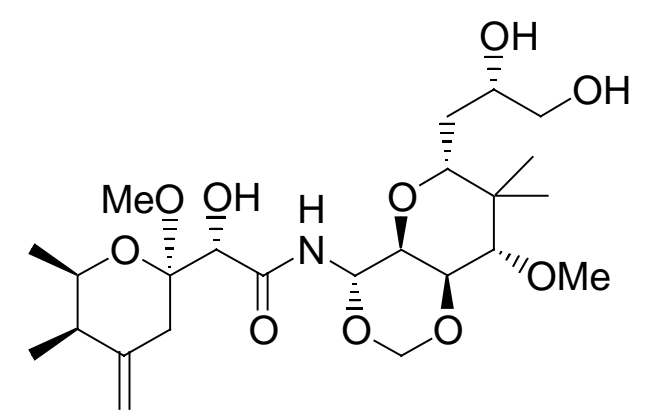

$1 a$

\section{Mycalamide A (1a)}

To a solution of carbonate 41 (2.1 mg, $2.6 \mu \mathrm{mol})$ in $\mathrm{MeOH}-\mathrm{H}_{2} \mathrm{O}-\mathrm{CH}_{2} \mathrm{Cl}_{2}(3: 1: 1,1 \mathrm{~mL})$ was added $\mathrm{NaIO}_{4}(5.7 \mathrm{mg}, 26 \mu \mathrm{mol})$ in one portion. The mixture was stirred for 2 hours, and then diluted with EtOAc $(10 \mathrm{~mL})$ and $\mathrm{Et}_{3} \mathrm{~N}(0.5 \mathrm{~mL})$, washed with $\mathrm{H}_{2} \mathrm{O}(2 \mathrm{~mL} \times 2)$, dried $\left(\mathrm{Na}_{2} \mathrm{SO}_{4}\right)$ and concentrated to give a white solid. The residue was dissolved in toluene $(0.25 \mathrm{~mL})$, whereupon $\mathrm{Et}_{3} \mathrm{~N}(0.25 \mathrm{~mL})$ was added. After refluxing for $10 \mathrm{~min}$, the reaction was poured onto saturated aqueous $\mathrm{NaHCO}_{3}(2$ $\mathrm{mL})$, and extracted with $\mathrm{Et}_{2} \mathrm{O}(5 \mathrm{~mL} \times 3)$. The combined organic extracts were dried $\left(\mathrm{Na}_{2} \mathrm{SO}_{4}\right)$ and concentrated to afford a yellow oil. To a solution of the crude oil in $\mathrm{MeOH}(0.5 \mathrm{~mL})$ was added a 
solution of $\mathrm{LiOH}(0.05 \mathrm{~mL}, 1.0 \mathrm{M})$ in $\mathrm{H}_{2} \mathrm{O}$. The mixture was stirred for 2 hours and concentrated to yield a white residue, which was dissolved in EtOAc $(10 \mathrm{~mL})$. The solution was washed with $\mathrm{H}_{2} \mathrm{O}(2 \mathrm{~mL} \times 2)$, dried $\left(\mathrm{Na}_{2} \mathrm{SO}_{4}\right)$ and concentrated to give a white oil. Purification of the crude oil by pipette column chromatography provided micalamide $\mathrm{A}(0.9 \mathrm{mg}, 69 \%$ for 3 steps $)$.

Data for 1a: $[\alpha]^{32}{ }_{D}=-98.9^{\circ}\left(\mathrm{c} 0.2, \mathrm{CHCl}_{3}\right)$; IR(neat) 3392, 2924, 2852, 1682, 1521, 1456, 1382, $1195,1093,1034 \mathrm{~cm}^{-1} ;{ }^{1} \mathrm{H}$ NMR $\left(500 \mathrm{MHz}, \mathrm{CDCl}_{3}\right.$ referenced to $\left.7.26 \mathrm{ppm}\right) \delta 7.49(\mathrm{~d}, J=9.7 \mathrm{~Hz}$, $1 \mathrm{H}), 5.89$ (t, J=9.7 Hz, $1 \mathrm{H}), 5.16(\mathrm{~d}, J=6.9 \mathrm{~Hz}, 1 \mathrm{H}), 4.90(\mathrm{~d}, J=6.9 \mathrm{~Hz}, 1 \mathrm{H}), 4.87$ (s, $1 \mathrm{H}), 4.78$ (s, $1 \mathrm{H}), 4.32$ (s, $1 \mathrm{H}), 4.24$ (dd, J=6.4, $10.1 \mathrm{~Hz}, 1 \mathrm{H}), 4.01$ (dq, J=2.7, 6.5 Hz, $1 \mathrm{H}), 3.87$ (dd, J=6.9, $10.1 \mathrm{~Hz}, 1 \mathrm{H}), 3.78$ (br s, $1 \mathrm{H}), 3.76(\mathrm{~m}, 1 \mathrm{H}), 3.66$ (dd, J=4.2, $7.8 \mathrm{~Hz}, 1 \mathrm{H}), 3.59$ (m, $1 \mathrm{H}), 3.58$ (s, $3 \mathrm{H}), 3.48$ (d, J=10.1 Hz, $1 \mathrm{H}), 3.40$ (dd, J=5.5, $10.6 \mathrm{~Hz}, 1 \mathrm{H}), 332$ (s, $3 \mathrm{H}), 3.18$ (br s, $1 \mathrm{H}), 2.39$ (m, 2 H), 227 (dq, J=2.8, 6.9 Hz, 1 H), 223 (br s, 1 H), $1.56(\mathrm{~m}, 2 \mathrm{H}), 1.21$ (d, J=6.4 Hz, $3 \mathrm{H}), 1.02$ $(\mathrm{d}, J=7.3 \mathrm{~Hz}, 3 \mathrm{H}), 1.00(\mathrm{~s}, 3 \mathrm{H}), 0.89(\mathrm{~s}, 3 \mathrm{H}) ;{ }^{13} \mathrm{C} \mathrm{NMR}\left(125 \mathrm{MHz}, \mathrm{CDCl}_{3}\right) \delta 171.59,145.45$, $110.57,99.68,86.75,79.02,78.99,74.30,73.69,72.82,71.45,71.21,69.73,66.44,61.76,48.90$, 41.56, 41.24, 33.67, 31.91, 23.04, 17.82, 13.50, 11.97; LRMS m/z $502\left(\mathrm{M}^{-}-\mathrm{H}\right)$; HRMS calcd for $\mathrm{C}_{24} \mathrm{H}_{40} \mathrm{NO}_{10}$ 502.2652, found : 502.2659.

\section{Literature Cited in Experimental Procedures}

(1) Mulzer, J.; Greifenberg, S.; Beckstett, A.; Gottwald, M. Liebigs Ann. Chem. 1992, 1131-1135.

(2) Takano, S.; Kurotaki, A.; Takahashi, M.; Ogasawara, K. Synthesis 1986, 5, 403-406.

(3) Katsuki, T.; Lee, A. W. M.; Ma, P.; Martin, V. S.; Masamune, S.; Sharpless, K. B.; Tuddenham, D.; Walker, F. J. J. Org. Chem. 1982, 47, 1373-1378

(4) Scheuplein, S. W.; Kusche, A.; Bruckner, R.; Harms, K. Chem. Ber. 1990, 917-925.

(5) Minami, N.; Ko, S. S.; Kishi, Y. J. Am. Chem. Soc. 1982, 104, 1109-1111.

(6) Doyle, M. P.; Davies, S. B.; Hu, W. Org. Lett. 2000, 2, 1145-1147. 